NBER WORKING PAPER SERIES

\title{
THE LONG-TERM SPILLOVER EFFECTS OF CHANGES IN THE RETURN TO SCHOOLING
}

\author{
Ran Abramitzky \\ Victor Lavy \\ Santiago Pérez
}

Working Paper 24515

http://www.nber.org/papers/w24515

\author{
NATIONAL BUREAU OF ECONOMIC RESEARCH \\ 1050 Massachusetts Avenue \\ Cambridge, MA 02138 \\ April 2018
}

We thank Jaime Arellano-Bover, Arun Chandrasekhar, Raj Chetty, Giacomo De Giorgi, Nathaniel Hendren, Matt Jackson, Magne Mogstad, Karthik Muralidharan, John Pencavel, Emmanuel Saez, Tom Zohar, Gabriel Zucman, seminar participants at Pontificia Universidad Catolica de Chile, Hebrew University, Warwick, and Stanford, and participants at the CEPR Labor Economics Conference at LSE 2016, the All California Labor Economics Conference at Stanford 2017, and GRIPS 2018 conference in Tokyo for useful discussions and suggestions. We thank Hadar Avivi, Elior Cohen, and Nadav Kunievsky for excellent research assistance. Victor Lavy acknowledges financial support from the European Research Council through ERC Advance Grant 323439 and from CAGE. The views expressed herein are those of the authors and do not necessarily reflect the views of the National Bureau of Economic Research.

NBER working papers are circulated for discussion and comment purposes. They have not been peer-reviewed or been subject to the review by the NBER Board of Directors that accompanies official NBER publications.

(C) 2018 by Ran Abramitzky, Victor Lavy, and Santiago Pérez. All rights reserved. Short sections of text, not to exceed two paragraphs, may be quoted without explicit permission provided that full credit, including $\odot$ notice, is given to the source. 
The Long-Term Spillover Effects of Changes in the Return to Schooling

Ran Abramitzky, Victor Lavy, and Santiago Pérez

NBER Working Paper No. 24515

April 2018

JEL No. J24

\begin{abstract}
We study the short and long-term spillover effects of a pay reform that substantially increased the returns to schooling in Israeli kibbutzim. This pay reform, which induced kibbutz students to improve their academic achievements during high school, spilled over to non-kibbutz members who attended schools with these kibbutz students. In the short run, peers of kibbutz students improved their high school outcomes and shifted to courses with higher financial returns. In the medium and long run, peers completed more years of postsecondary schooling and increased their earnings. We discuss three main spillover channels: diversion of teachers' instruction time towards peers, peer effects from improved schooling performance of kibbutz students, and the transmission of information about the returns to schooling. While each of these channels likely contributed to improving the outcomes of peers, we provide suggestive evidence that the estimates are more consistent with the effects operating mainly through transmission of information.
\end{abstract}

Ran Abramitzky

Department of Economics

Stanford University

579 Serra Mall

Stanford, CA 94305

and NBER

ranabr@stanford.edu

Victor Lavy

Department of Economics

University of Warwick

Coventry, CV4 7AL

United Kingdom

and Hebrew University of Jerusalem

and also NBER

v.lavy@warwick.ac.uk
Santiago Pérez

University of California, Davis

1116 Social Sciences and Humanities

Davis, CA 95616

seperez@ucdavis.edu 


\section{Introduction}

We study the short- and long-term spillover effects of a change in the returns to schooling. Starting in the late 1990s, kibbutzim (socialist-oriented communities in Israel) changed their decades-long policy of equal income sharing to one of market-based wages, resulting in a substantial increase in the financial returns to schooling. In an earlier study, Abramitzky and Lavy (2014) found that this pay reform led to significant gains in academic achievements of kibbutz high school students. In this paper, we shift attention to the spillover effects of this reform on students from non-collective communities who attended school with kibbutz members. Unlike in the case of kibbutz members, we are able to follow their school peers from high school, through postsecondary schooling, and into the labor market. ${ }^{1}$

The shift away from equal sharing could spill over to school peers of kibbutz members in three main ways. First, through transmission of information on the returns to schooling. The pay reform was highly salient for kibbutznik high-school students because their parents could experience large decreases or increases in their earnings depending on their educational and skill levels. Hence, peers were likely exposed to first-hand and salient information about the returns to human capital through their daily interaction with kibbutzniks (kibbutz members). Second, through peer effects - peers of kibbutzniks might have decided to study harder because their kibbutz-peers started to study harder. Third, the improvement in high school performance among kibbutz students might have freed teachers' time to the advantage of their peers.

Our identification strategy takes advantage of the fact that some kibbutzim reformed earlier than others and that some grades (school-cohorts) had students from early reformed kibbutzim and some grades did not. We identify spillover effects using a difference-in-differences approach, comparing the peers of students from kibbutzim that reformed early to the peers of students from kibbutzim that reformed late, before and after the implementation of the early reforms. Our identification assumption is that in the absence of the reforms, the outcomes of the peers of students from early reformed kibbutzim would not have been systematically different than the outcomes of peers of students from kibbutzim that reformed late. We provide evidence that peers of students from kibbutz that reformed early and peers of students from kibbutz that reformed late were similar in their observable characteristics and pre-reform schooling outcomes, both in terms of baseline levels and pre-reform trends.

We start by using administrative records collected by the Israeli Ministry of Education to study the effects of the reform on short-term schooling outcomes of kibbutz peers. We find that

${ }^{1}$ Such long-term analysis is not feasible for kibbutz members as they cannot systematically be observed in the labor market. 
peers of early reformers improved their high school performance. The high school completion rate increased by 1.6 percentage points (relative to baseline of $95.5 \%$ ), average matriculation exams scores went up by 2.8 points (baseline of 70.9 points) and the matriculation and university qualified matriculation rates increased by 9 and 9.5 percentage points, respectively (baselines of 61 and $58 \%$, respectively). Also, in line with the results in Abramitzky and Lavy (2014), we find that the effects are stronger on males and on students from relatively low socioeconomic status.

We then combine the high school records with National Social Security administrative data to examine the spillover effects of the reform on longer-term outcomes (when students were in their early 30s) such as whether they attained post-secondary schooling, their employment status and whether they received employment benefits, and their earnings. Treated peers experienced economically meaningful gains in terms of post-secondary schooling attainment. These gains were mainly in university schooling, which requires a matriculation certificate, and not in academic colleges schooling, a lower quality tier of academic institutions in Israel. University enrollment of treated peers increased by 9.5 percentage points and completed years of university schooling increased by 0.5 . Moreover, we find an 8 percent increase in annual earnings and a $1.5 \%$ decline in the probability of receiving unemployment benefits. These improvements in labor market outcomes are consistent with the higher levels of post-secondary schooling attained by treated peers.

Our setting does not enable us to separately identify which precise channels of social interaction (information transmission, peer effects, teacher effects) resulted in the spillover effects that we document: each of these channels likely contributed to improving the outcomes of peers to some extent. However, we provide suggestive evidence that the estimates are more consistent with the effects operating mainly through transmission of information about the returns to schooling rather than through teacher effects or peer effects from improved schooling performance of kibbutzniks. In particular, we show that consistent with a model of information transmission (Banerjee, Chandrasekhar, Duflo and Jackson 2013), the effects are of similar magnitude as long as the fraction of directly treated students in the grade is high enough.

This paper contributes to two strands of literature. First, it contributes to the literature on the spillover effects of social programs. Such spillover effects could be large, because many nonparticipants can be exposed indirectly to social programs through their interactions with participants. However, it is empirically challenging to identify such effects. Recent papers on spillover effects take advantage of settings in which a treatment is experimentally or quasiexperimentally assigned at the group level, but only a subset of individuals within the group is directly treated. The identification of spillover effects then stems from comparing untreated individuals in treated groups to untreated individuals in (un)treated groups. These studies have 
looked at spillover effects in the context of retirement decisions (Duflo and Saez, 2003), health interventions (Miguel and Kremer, 2004), conditional cash transfers (Angelucci and De Giorgi, 2009; Bobonis and Finan, 2009; Lalive and Cattaneo, 2009), active employment programs (Crépon, Duflo, Gurgand, Rathelot and Zamora, 2013), program participation (Dahl, Løken, and Mogstad, 2014), and expanding access to college education (Bianchi, 2016).

We contribute to the literature on spillover effects in two main ways. First, unlike previous studies, we are able to measure the short and long run spillover effects of a policy, including the consequences in the labor market in adulthood. Second, we show in the context of a school learning environment that spillover effects induce strong behavioral changes among those not directly treated. The spillover effects studied in Kremer and Miguel (2004) are activated through a health environment mechanism, largely without an effect on student's academic test scores. By contrast, in our paper, these effects occur mostly through a behavioral response. Therefore, our estimates reflect a similar reaction to that studied in Duflo and Saez (2003) and Dahl, Løken, and Mogstad (2014), where spillover of information is likely the main transmission channel.

More broadly, the pay reform can be interpreted as a sharp decrease in the marginal tax rate faced by kibbutz's members. While there is a substantial literature studying the effects of such changes on the labor supply of directly affected individuals, there is more limited evidence on their impacts on not explicitly targeted individuals. Hence, from a public economics perspective, this paper sheds light on how redistribution can affect investments in human capital -and hence labor supply decisions- of individuals not explicitly targeted by redistribution.

The rest of the paper is structured as follows. Section 2 presents the background of kibbutzim and the pay reform, and of the Israeli high school system. Section 3 describes the data and sample restrictions. Section 4 presents the empirical framework and identification strategy. Section 5 presents the results on the effect of the reform on high school outcomes. Section 6 presents the results on the long-term effects on post-high school education and labor market outcomes. Section 7 provides evidence on mechanisms and section 8 concludes.

\section{Brief background}

\section{a. Kibbutzim and the pay reform}

Kibbutzim are voluntary communities that have provided their members with a high degree of income equality for almost a century. ${ }^{2}$ Traditionally, all kibbutzim were based on full income sharing between members. Each member of a kibbutz was paid an equal wage, regardless of her

\footnotetext{
${ }^{2}$ For a detailed background on kibbutzim and the pay reform, see Abramitzky (2018).
} 
economic contribution to the community. Specifically, there were no monetary returns to schooling in the kibbutz, as members earned the same regardless of their education levels.

Unlike American communes, kibbutzim are not isolated from the Israeli society as a whole, and their members are well aware of their outside options (Abramitzky 2011). Kibbutzim are usually located close to cities and their members often have family outside of the kibbutz. Crucial to our setting, kibbutz-born children typically attend school outside their kibbutz, where they interact with members of other kibbutzim and residents of surrounding villages and towns.

The episode that we study is a pay reform that kibbutzim in Israel adopted beginning in 1998. ${ }^{3}$ In reformed kibbutzim, members' wages reflected market wages so that members were allowed to keep a substantial fraction of their earnings for themselves. For members who worked outside their kibbutzim (about a fourth of all members), market wages were the wages they received from their employers. For members who worked inside, market wages were based on the wages of non-kibbutz workers of similar occupation, education, skills, and experience. A kibbutz 'tax' was deducted from members' gross wages to guarantee older members and low wage earners in the kibbutz a minimum wage.

A survey of three thousand kibbutz members conducted by Pilat Institute in 2004 revealed large wage differences by occupation and education. For example, a director of a kibbutz sector (e.g., the agricultural sector or industry sector) might earn close to 30,000 NIS (about US $\$ 8,000$ per month), and members in leading positions such as the main secretary (chairman) and the treasurer of the kibbutz earned over 15,000 NIS (about \$4,000) per month. Over 80 percent of members holding such positions have academic degrees. In contrast, a member working as a menial laborer in the kitchen or in the laundry, without a post high school academic education, earned less than 4,000 NIS (about \$1,000) per month. A more recent survey in 2009 that included 180 kibbutzim that reformed their pay structures again revealed large pay gaps within kibbutzim. The survey looked only at members who worked inside kibbutzim; it provided data on the monthly wages of 120 different occupations. The highest gross monthly income recorded in the survey was 17,500 NIS $(\$ 4,600)$ and the lowest, 4,100 NIS $(\$ 1,080)$. This range suggests large income inequality, which would most likely be even higher if the wages of the members employed outside the kibbutz were taken into account. ${ }^{4}$

\footnotetext{
3 These pay reforms were a response to changing external pressures and circumstances facing kibbutzim, including a decline in world prices of agricultural goods, bad financial management, and a high-tech boom during the mid-1990s, which increased members' outside options considerably. Most notably, the 1985 stabilization program in Israel following a few years of high inflation, which raised interest rates dramatically and left many kibbutzim with huge debts they could not repay. See Abramitzky (2018).

4 This information is provided in the daily newspaper Haaretz [in Hebrew], Sept. 17, 2009, www.haaretz.co.il/hasite/objects/pages/PrintArticle.jhtml ?itemNo=1115205.
} 
The move from equal sharing to differential pay signaled strongly to young adults in the kibbutzim an increase in the financial rewards to human capital. This increase in the return to skills was noticeable within a family, as students' parents experienced a decrease or increase in their earnings depending on their skills. Furthermore, the pay reform has been the most discussed topic in kibbutzim since the reforms started. The new productivity-based sharing rules were hotly debated and voted on by members in kibbutzim; booklets elaborating on the reforms were distributed to all members; and the reforms also received substantial attention in the media both in Israel and abroad. Further details on the pay reform are provided in Abramitzky and Lavy (2014).

\section{b. High school and post high school schooling in Israel}

Israeli high school students are enrolled either in an academic track leading to a matriculation certificate (bagrut) or in an alternative track leading only to a high school diploma. The bagrut is completed by passing a series of national exams in core and elective subjects taken by the students between 10 th and 12 th grade. Thus, bagrut certificates are typically obtained at the end of senior year (twelfth grade) or later. ${ }^{5}$

Students choose to be tested at various proficiency levels, with each test awarding one to five credit units per subject, depending on difficulty. Some subjects are mandatory and many must be taken for at least three units. Advanced level subjects are those subjects taken at a level of four or five credit units. A minimum of 20 credit units is required to qualify for a bagrut certificate, though some university study programs require more, and students must also satisfy distribution requirements. About 52 percent of all high school seniors received a matriculation certificate in the 1999 and 2000 cohorts (Israel Ministry of Education 2001). Roughly 60 percent of those who took at least one bagrut subject test ended up receiving a bagrut certificate.

After completing high school, students can decide to continue their studies in various postsecondary schooling institutions. The post high school schooling system in Israel includes seven universities (one of which confers only graduate and $\mathrm{PhD}$ degrees), and over 50 colleges that confer academic undergraduate degrees (some of these also give master's degrees). ${ }^{6}$ All universities require a bagrut diploma for enrollment. Most academic colleges also require a bagrut, though some look at specific bagrut diploma components without requiring full certification. For a given

\footnotetext{
${ }^{5}$ Similar high school matriculation exams are found in many countries and in some states in the United States. Examples include the French Baccalaureate, the German Certificate of Maturity, the Italian Diploma di Maturità, and the New York State Regents examinations.

${ }^{6}$ A 1991 reform sharply increased the supply of postsecondary schooling in Israel by creating publicly funded regional and professional colleges.
} 
field of study, it is typically more difficult to be admitted to a university than to a college. Hence, we expect improvements in outcomes related to the bagrut to translate into improvements in postsecondary schooling outcomes and, in particular, to university-related outcomes. The national university enrollment rates for the cohort of graduating seniors in 1995 (through 2003) was 27.6 percent and the respective rate for academic colleges was 8.5 percent. $^{7}$

\section{Data and Sample Restrictions}

\section{a. High school outcomes}

The first part of our empirical analysis is based on administrative records collected by the Israeli Ministry of Education. In these records, we observe the schooling outcomes of students starting high school from 1994 to 2000. Each record contains individual level and class identifiers, as well as demographic information on background characteristics of the students. Importantly, the demographic information includes the home address of each student, allowing us to identify which of them resided in a kibbutz by the start of $10^{\text {th }}$ grade, the first year of high school.

We focus on the following schooling outcomes that are available for all the sample years: an indicator for whether the student graduated from high school, the average score in the matriculation exams, an indicator for whether the student received a matriculation certificate (bagrut) and an indicator for whether the student received a matriculation certificate that meets university entrance requirements. About 15 percent of the students in the sample did not take the matriculation exams. These students get zero values in the average matriculation score. The other three high school outcomes that we use - matriculation status, matriculation status that meets university entrance requirements, and the high school completion indicator - do not require such imputation.

To identify students from early and late reformed kibbutzim, we merged the student level data with kibbutz level data collected by the Institute for Research of the Kibbutz and the Cooperative Idea (Getz 1998-2004). These data include several characteristics of kibbutzim, including whether they adopted the pay reform and its date of implementation.

\section{b. Post-high school outcomes}

We combine the data on high-school outcomes with annual data on post-secondary schooling and economic outcomes in adulthood. To do so, we link students from their schools to

\footnotetext{
${ }^{7}$ These data are from the Israel Central Bureau of Statistics, Report on Post-Secondary Schooling of High School Graduates in 1989-1995 (available at: http://www.cbs.gov.il/publications/h_education02/h_education_h.htm).
} 
their post-secondary outcomes using administrative data provided by Israel's National Insurance Institute (NII).

In these data, we observe two sets of outcomes for each of the students in our sample. First, we observe post-secondary schooling attainment, including the type of post-secondary schooling institution attended, if any, and the number of years of schooling completed in each type of institution. The post-secondary schooling outcome variables of interest are indicators of ever having enrolled in a university or in an academic college, and the number of years of schooling completed in these two types of academic institutions. Even after accounting for compulsory military service, we expect that most students who enrolled in post-high school education, including those who continued schooling beyond undergraduate studies, to have graduated by age 30 .

Second, we observe year-by-year labor market outcomes from high school graduation to 2014, including employment status, information on unemployment benefits and annual earnings in the formal sector. Individual earnings data come from the Israel Tax Authority (ITA). Filing tax forms in Israel is compulsory only for individuals with non-zero self-employment earnings but ITA has information on annual gross earnings from salaried and non-salaried employment, which they transfer annually to NII, including number of months of work in a given year. Using these data, NII produces an annual series of total annual earnings from salaried work and self-employment. Following NII practice, individuals with positive (non-zero) number months of work and zero or missing value for earnings are assigned zero earnings. We were allowed restricted access to these data in the NII protected lab in Jerusalem.

\section{c. Sample restrictions}

We restrict the analysis to schools and grades that satisfy the following set of conditions: (1) school is present in every sample year (1995 to 2000), (2) school has at least two students from either early (1998-2000) or late (2003-2004) reformed kibbutzim, both before (1995-1996) and after the early reforms (1999-2000), (3) grade has a positive number of students from early reformed kibbutzim and/or a positive number of students from late reformed kibbutzim. In the robustness section of the paper, we assess the sensitivity of the results to these sample restrictions. The goal of these restrictions is to capture the set of schools that are typically attended by students from early and late reformed kibbutzim. In addition, although some of the peers of early reformers and late reformers are kibbutz members from different kibbutzim - for instance, from kibbutzim that never reformed-, we further restrict the sample of peers to non-kibbutz members.

\section{Empirical Strategy}


To identify the spillover effects of the pay reform, we take advantage of differences in the timing of the implementation of the reform in a difference-in-differences (DID) framework. Our first difference compares non-kibbutz members in grades with students from kibbutzim that reformed early (1998-2000) to non-kibbutz members in grades with students from kibbutzim that reformed late (2003-2004). Our second difference compares cohorts of students who started highschool before (1995-1996) and after (1999-2000) the implementation of the early reforms.

In our baseline empirical exercise, we estimate the following regression:

$$
Y_{i s c}=\alpha_{s}+\alpha_{c}+\beta_{1} \text { Treated }_{s c}+\beta_{2} \text { Treated }_{s c} \text { X After } \text { Af }_{c}+\varepsilon_{i s c}
$$

where $Y_{i s c}$ is an outcome of student $i$ in cohort $c$ in school $s, \alpha_{s}$ are school fixed effects, $\alpha_{c}$ are cohort fixed effects, Treated ${ }_{s c}^{8}$ is an indicator variable that captures whether a student is exposed to peers from early reformed kibbutzim, and Treated $_{s c} X$ After $_{c}$ is the interaction of interest, indicating if a student was exposed to early reformers and attended school in the post-reform period. We also estimate a version of equation 1 in which we add a vector of student's background characteristics including gender, mother's years of education, father's years of education, number of siblings and ethnicity indicators. In all the regressions throughout the paper, we cluster the standard errors at the school level.

We define treatment status at the grade (school-cohort) level, based on a student's peers in the first year of high school $\left(10^{\text {th }}\right.$ grade). We choose the grade rather than the class as the level of analysis as classes are potentially endogenous, as parents and school authorities may have discretion in placing students in different classes within a grade (Hoxby 2000, Lavy and Schlosser 2011). We note that this is not a very restrictive compromise because in our baseline sample there is a very high correlation (above 0.7 ) between treatment status defined at the grade and treatment status defined at the class level. ${ }^{9}$ Similarly, we define treatment status based on a student's peers on the first year of high school since subsequent changes might also be endogenous.

In our baseline exercise, a grade is defined as treated if the number of students from early reformed kibbutzim is greater than zero. Our comparison group comprises grades in which the number of students from early reformed kibbutzim is zero, but the number of students from late reformed kibbutzim is positive. In section 7, we also report estimates in which we allow the

\footnotetext{
${ }^{8}$ Note that because treatment status is defined at the grade and not at the school level, the treatment indicator is not perfectly correlated with the school fixed effects.

${ }^{9}$ Not surprisingly given this high correlation, we show in the robustness section that the results are similar if we instrument treatment status defined at the class level with treatment status defined at the grade level.
} 
intensity of the treatment to vary based on the fraction of early reformers in the grade. In the robustness section, we report an alternative specification in which we use the same control group but we define a grade as being treated if the number of students from early reformed kibbutzim is greater than zero and the number of students from late reformed kibbutzim is zero.

Table 1 presents the sample of schools, grades and students that we use in our analysis. In total, our sample includes students from 31 high schools in Israel. Note that students from all kibbutzim in Israel are attending not much larger number of schools, so our sample of schools represents a high proportion of schools attended by students from kibbutzim. Our pre-treatment sample includes a total of 3,177 students and our post-treatment sample includes 4,529 students. There are a total of 61 grades in the pre-treatment period, with 48 in the treatment and 13 in the control group. The number of grades in the post-treatment period is 62, out of which 52 are in the treatment and 10 in the control group. The average grade size in the sample is approximately 125 . On average, each grade in the treatment group contains approximately 20 students from early reformed kibbutzim. Each grade in the control group includes approximately 10 students from late reformed kibbutzim.

Our identification assumption is that the exact timing of the reform is orthogonal to the potential outcomes of the peers of students in early and late reformed kibbutzim. In other words, we assume that in the absence of the reforms, the outcomes of the peers of students from early reformed kibbutzim would not have been systematically different than the outcomes of peers of students from kibbutzim that reformed late.

We provide evidence that this assumption is plausible. First, we show that students with peers from early reformed kibbutzim were similar to students with peers from late reformed kibbutzim, both in terms of their background characteristics and in terms of their schooling outcomes before the reform. Second, we show that peers of early reformers were on a similar time trend to peers of late reformers in the pre-reform period. Third, we show that there is no evidence of sorting of peers -based on observable characteristics - as a result of the reform. That is, we do not find evidence of a differential change in the pool of peers of early reformers after the reform. Fourth, we perform a placebo exercise assuming that the reform happened on an earlier year and find no effects.

Peers of early reformers are similar to peers of late reformers. In Table 2, we show that the peers of early reformers are similar to the peers of late reformers. In columns 1 and 5, we report the mean and standard deviation (in parentheses) of each of the student's background characteristics and outcomes, before and after the early reforms. In columns 2, 3, 6 and 7 we display the mean and standard deviation of each of these variables, separately for treatment and control 
students and before and after the early reforms. In columns 4 and 8, we report the estimated coefficient and standard error (in parentheses) in a regression of each of the variables on a treatment indicator and cohort fixed effects. In particular, we estimate for each of the background characteristics $\left(X_{i s c}\right)$ and separately for the pre and post-reform periods the following regressions:

$$
X_{i s c}=\alpha_{c}+\beta \text { Treated }_{s c}+\varepsilon_{i s c}
$$

Similarly, we estimate for each of the schooling outcomes, $Y_{i s c}$ :

$$
Y_{i s c}=\alpha_{c}+\beta \text { Treated }_{s c}+\varepsilon_{i s c}
$$

Panel A of Table 2 shows that the background characteristics of students and their families are similar in both groups, both before and after the early reforms. Father's years of schooling are lower in the control group in the pre-treatment period, a difference of 0.6 years. Only mother's years of schooling in the pre-treatment period is significantly different across the two groups. The differences in parental years of schooling between the treatment and control groups becomes smaller and not significant in the post-treatment period, 0.39 for the fathers and 0.53 for mothers.

Differences in the average number of siblings are small and not statistically significant, both in the pre- and the post-treatment periods. On average, students have between 2.2 and 2.6 siblings in both groups. The treatment and control groups are also similar with respect to their ethnic origins. The more salient difference among the two is that students in the control group are 5 percentage points more likely to belong to the Asia-Africa ethnic group. Finally, students in the control and treatment groups are also relatively similar in terms of average family income.

Panel B of Table 2 shows that, consistent with the small differences in background characteristics, schooling outcomes are similar across the two groups in the pre-reform period. The rate of students graduating from high school is 0.7 percentage points smaller in the treatment group, relative to a mean of $95 \%$. The mean matriculation score is also similar across the two groups, a difference of 0.6 points in favor of the treatment group. The fraction of students obtaining a matriculation certification is slightly higher in the treatment group, both for the regular and the university qualified. None of these differences are statistically significant at the conventional levels.

Panels C and D of Table 2 show that students from pre-reform cohorts were also similar in terms of post-secondary schooling outcomes. The only statistically significant difference is that treated peers had a higher number of months of unemployment benefits and consequently received higher annual unemployment related payments. 


\section{Peers of early reformers were on a similar time trend than peers of late reformers. In}

table 3, we use the pre-reform data (1994 to 1997) to estimate differential time trends in outcomes for treatment and control grades. To do so, we interact the treatment indicator with a series of cohort dummies corresponding to students starting 10th grade in each of these years. The interaction terms of the treatment indicator with the cohort dummies are all small and not significantly different from zero; we also note that some are positive and others are negative, lacking any consistent pattern. This conclusion is supported by the fact that, based on the F-tests presented in the table, we cannot reject the hypothesis that all the interaction terms are jointly equal to zero for any of the short-run high-school outcomes, including a summary index of these outcomes (described in detail below).

No sorting across schools as a result of the reform. One possible violation of our identification assumption is the endogenous sorting of students across schools as a result of the reform. This sorting might have happened for two reasons. First, students from kibbutzim that reformed early might have decided to enroll in better quality schools after the reform. Note that because our analysis includes school fixed effects, for this type of sorting to bias our results students from early reformed kibbutzim must have switched to schools on a better time trend. Second, the prospects of sharing a school with early reformers might have attracted a better pool of peers in the post-reform period to those schools typically attended by early reformers. In this case, our estimation strategy would be capturing a compositional change in the group of peers rather than spillover effects from the pay reform.

A number of features of our setting and empirical strategy make this concern less worrisome. First, note that we define treatment status based on the first year of high school. Hence, if there were any sorting, it would have needed to occur before students actually started high school. Second, we define treatment status at the grade (school-year) level, which rules out sorting occurring at the class level. Third, note that by restricting the sample to schools attended by kibbutz members both before and after the early reforms, we largely rule out the effects being driven by kibbutz students attending a different set of schools after the reforms.

Yet, the possibility of sorting is a threat to our identification strategy. We provide two pieces of evidence that suggest that this sorting did not occur. First, we document that early reformers did not switch to a different set of schools in response to the reform. In practice, most students living in the same kibbutz also attend the same high school. Collapsing our data at the kibbutz-year level, we find that in $76 \%$ percent of the cases all the students in the kibbutz attended the exact same high school, and that the average share of students attending the largest school within a kibbutz-year is $95 \%$. Indeed, the median number of schools per kibbutz-year is 1 and in $88 \%$ of the kibbutz-years students attended at most two different schools. Moreover, in $97 \%$ of the 
kibbutz-years, the most attended school was the same as in the previous year. Importantly for our identification strategy, we do not observe any systematic pattern of school switching before and after the early reforms. The mean and median number of schools remains similar in kibbutz that reformed earlier. In addition, the share of students who attend the largest school is also stable. These findings are consistent with the fact that, unlike in the US context, there is very little mobility between schools in the Israeli educational system (Lavy and Schlosser, 2011).

Second, there is no evidence of a systematic change in the observable background characteristics of peers after the early reform. To formally test for this possibility, we regress each of the background characteristics on a treatment indicator and an interaction between the treatment indicator and a post indicator. If students from earlier reformed kibbutzim were not systematically sorting across schools as a result of the reform, then we should not find any differential change in the background characteristics of their peers relative to the control group. More precisely, we estimate:

$$
X_{i s c}=\alpha_{c}+\beta_{1} \text { Treated }_{s c}+\beta_{2} \text { Treated }_{s c} \text { X After } \text { fr }+\varepsilon_{\text {isc }}
$$

where $X_{i s c}$ corresponds to a background characteristic of student $i$ in school $s$ in cohort $c$. In the absence of sorting, we expect to find that $\beta_{2}=0$.

Table A.1 in the online appendix shows the results of estimating this specification for each of the background characteristics that we observe in our data. Peers appear to look slightly worse in terms of parental educational background in the post-reform period relative to the control group, but better in terms of family income. All the other differences are small and statistically nonsignificant.

Spillovers outside the classroom and anticipation effects. We cannot rule out that students who did not share a grade with early reformers still knew about the pay reforms happening in the kibbutz. If information about the pay reform was equally salient irrespective of sharing a grade with an early reformer, then our estimates will just capture the peer effects component of the overall spillover effects (and will likely be biased downwards). In addition, students from kibbutz that reformed late might have increased their effort in anticipation to the late reforms. Note, however, that in our design we focus on late reforms that took place at least three years after the early reforms, making such anticipation less plausible. In Abramitzky and Lavy (2014), we empirically document the lack of anticipation effects among students in late reformed kibbutzim.

Why not using peers of never reformers. Students from kibbutz that never reformed were significantly different than those from either early or late reformed kibbutzim in terms of high school outcomes (Abramitzky and Lavy 2014). In Table A.2 in the online appendix, we show that these differences were also present among their peers. Hence, we believe that the parallel trends 
assumption that is required for the DID exercise to identify the causal spillover effects of the pay reform becomes less plausible if we add never reformers.

\section{Short-Term Effects on High School Outcomes}

\section{a. Basic results}

In Panel A of Table 4, we present the results of estimating equation (1) using the high school outcomes as dependent variables. We report two main specifications for each of the high school outcomes. In the first row, we report the simple DID, without any further controls other than the school fixed-effects. In the second row, we include student's background characteristics as additional controls. In each of the rows, we show the estimated coefficient of interest corresponding to the treated group in the post-reform period.

The table shows a positive coefficient on all the schooling outcomes (columns 1 to 4). First, the fraction of students completing high school increases by approximately 1.6 percentage points, relative to an already high mean completion rate of $95 \%$ (column 1), implying a 2 percent improvement. Second, the mean matriculation score increases by 2.3 points, relative to a mean matriculation score of 70 points (column 2), effectively a 3 percent increase. Note that these effect sizes are relatively small and that neither of the previous estimates is precisely measured.

We next report our estimated effects on the probability of obtaining a matriculation certificate (column 3) and of obtaining a university-qualified matriculation certificate (column 4). We find an increase of 7.8 percentage points in the matriculation rate, relative to a pre-reform level around $61 \%$, a 13 percent improvement. The increase is of similar magnitude in the universityqualified matriculation, although the pre-reform mean is lower in this case (57\%). Note that as a result of the balancing documented in Table 2, the point estimates exhibit little sensitivity to controlling for student's background characteristics (row 1 versus row 2 estimates).

The positive impact on high-school outcomes holds when we estimate aggregate treatment impacts, using a summary index instead of individual outcomes to account for multiple inference (Kling et al. 2007). In column 5, we present the results of a specification that uses this summary index measure as the dependent variable. This index is computed as the equally weighted average of each of the high-school outcomes' z-scores. The z-scores are calculated by subtracting the control group mean and dividing by the control group standard deviation. Thus, each component of the index for the control group has mean 0 and standard deviation 1 . The results using this summary measure also indicate an overall improvement in high-school performance.

One testable implication of our identification assumption is that we should not find any effects of the reforms on unaffected cohorts, i.e. students who attended school before the early 
reforms. To directly test this implication, in Panel B of Table 4, we report the results of a placebo exercise in which we estimate the same DID specification as in equation (1), but assuming that the early reforms happened in 1996 instead of 1998. In particular, we compare students in grades with students from kibbutzim that reformed early to grades without early reformers, before (1994-1995) and after (1996-1997) the placebo reforms.

Reassuringly, the point estimates in this exercise are all small in magnitude, some of opposite sign, relative to the estimates in Panel A and none of them is statistically significant. Together with the lack of any pre-reform time trends documented in Table 3, this exercise provides

further support to our assumption that the outcomes of peers in the treatment group would have been similar on average to those in the control group in the absence of the reform.

How large are the spillover effects relative to the direct effect on kibbutz students. A simple comparison between the size of the spillover effects we document here and the direct effect on kibbutz students estimated in Abramitzky and Lavy (2014) suggests that the effects are of similar magnitude. However, Abramitzky and Lavy (2014) compared students in kibbutzim that reformed early to students in kibbutzim that reformed late, before and after the implementation of the early reforms. If students from early reformed kibbutzim overlapped in schools with students from late reformed kibbutzim, students in the latter group could have been affected by the early reforms through peer effects, although the channel of information on return to schooling is less relevant for them because their kibbutz had not reformed yet. Such peer effects would have led to a downward bias in the direct effects as estimated in Abramitzky and Lavy (2014). To test this possibility, we replicate the results of Abramitzky and Lavy (2014) (results available upon request) using a sample that excludes grades with students from both early and late reformed kibbutzim. Using this restricted sample, we find that the direct effects are in all cases larger than in the baseline sample. This finding is consistent with the aforementioned attenuation bias, although we note that it is based on a very small sample where balancing between the treatment and control groups does not hold as in the full sample. Hence, while the evidence is consistent with the possibility that Abramitzky and Lavy (2014) underestimate the direct effects, we can only provide suggestive evidence on the direction and magnitude of this underestimation.

\section{b. Alternative specifications and robustness}

We next assess the sensitivity of our main results on high school outcomes. First, in the third row of Panel A of Table 4, we show that the results are similar when we estimate a crosssectional regression using only the post early reforms cohorts. This finding implies that the DID estimates are driven by improvements in the treatment group rather than by a decline in 
performance of the control group. This panel also shows that the pre-reform outcomes were very close in both groups.

Second, in Table A.3 in the appendix we show that the results are similar when we add a student's family average earnings in 2000-2002 as an additional control in the DID estimation. We prefer a multi-year average because it is more likely to be correlated with the permanent level of family resources. Note that performing this exercise was not possible in Abramitzky and Lavy (2014), since family income cannot be properly measured among families who live in the kibbutz.

Third, in Table A.4 we re-estimate equation 1 dropping school fixed effects in the regression. The results are similar as well, which is in line with the lack of pre-reform differences in the schooling outcomes of the treatment and control groups.

Fourth, in appendix Table A.5 we present results from two alternative samples. In the first we restrict the analysis to schools and grades that have at least three students from either early (1998-2000) or late (2003-2004) reformed kibbutzim, both before (1995-1996) and after the early reforms (1999-2000). In the second sample we require at least 6 students. We jump from 3 to 6 students because there are no schools with 4 or 5 such students. Remarkably, the estimates we obtain from these two smaller samples are very similar to the estimates obtained when the restriction is at least 2 students. For example, the effect on high school completion is 0.018 in the $2+$ and $6+$ samples. The effect on matriculation certification is 0.088 and 0.079 , respectively. These similarities are obtained even though the sample size declines by 18 percent.

Fifth, in appendix Table A.6 we show that the results are similar when we implement an instrument variables strategy in which we instrument a class-level treatment indicator with the treatment indicator defined at the grade level. The validity of this instrument rests on the assumption that cohort-to-cohort changes in the exposure to students from reformed kibbutzim is random conditional on school fixed effect that account for any confounding factors. This is a reasonable assumption because within a short period of time it is safe to assume that students from adjacent cohorts in a given school have similar characteristics and face the same school environment, except for the fact that one cohort has more students from reformed kibbutzim due to purely random factors. We note that the reduced form effect of this instrument is exactly the grade level treatment effect that we presented above. Secondly, note that within a school the proportion of students from reformed kibbutzim in a grade is highly correlated with the students from reformed kibbutzim in a class, which forms the first stage regression in this 2SLS set up. The IV point estimates presented in Table A.6 are higher in absolute value than our baseline estimates, which is consistent with the fact that we expect closer interactions among students at the class than at the grade level. 
Finally, we report a specification in which we keep the same students in the control group but drop from the treatment group all the grades with students from both early and late reformed kibbutzim. That is, we compare grades with early reformers but no late reformers to grades with late reformers but no early reformers, before and after the implementation of the early reforms. We report the results of this exercise, as well as the corresponding balancing and sample size Tables in online appendix Tables A.7, A.8. and A.9. The results are similar to those in our main specification both qualitatively and quantitatively. Note, however, that the sample size goes down reflecting the more stringent definition of the treatment group.

\section{c. Heterogeneous effects}

Differences between men and women. Previous research on the effectiveness of schooling interventions has shown differences in the responsiveness of men relative to women (for example, Angrist and Lavy 2009). To test for this possibility, in Panel (i) of Table 5, we stratify the sample based on the gender of students. To do so, we use the sample that includes at least six students in a cohort that are from kibbutzim that reformed early to make sure that this group includes female and male students as well as students from low and high socioeconomic background. In the last row of each panel of Table 5, we include the p-value for the hypotheses that the effects are equal across genders.

All the point estimates suggest that the effects are larger among men. This pattern is similar to what Abramitzky and Lavy (2014) found for the direct effect of the reform on kibbutz students. The high school graduation rate of men goes up by 3.6 percentage points. The mean of the matriculation score of men increases by 5.3 points. The fraction of male students obtaining a matriculation certification goes up by 12.3 percentage points and the fraction obtaining a university-qualified matriculation goes up by 10.2 percentage points. Moreover, the summary index of all these outcomes is up by $0.224(\mathrm{SD}=0.074)$ among males. In contrast, the effects are in most cases close to zero (and even negative in some cases) and not significant in the female subsample. Note, however, that in the cases of high school completion and the university qualified matriculation we cannot reject at the conventional levels the hypotheses that the effects are the same across both genders.

Differences by social background of students. In Panel (ii) of Table 5, we stratify the sample based on the education of the student's mother (below and above median education). We use for this estimation the same sample used when stratified by gender. We find that the effects are larger among students with below median mother education, and largely insignificant for the high socio-economic status families. This pattern is also consistent with the findings in Abramitzky and 
Lavy (2014) on the direct effects of the reform on kibbutz students. However, in this case, for each of the high school outcomes we cannot reject - at the 10 percent level - the hypothesis that the effects are the same across the two subgroups.

\section{Long-Term Effects}

We next analyze whether the improvements observed during high school resulted in longterm gains in educational and labor market outcomes. To do so, we link our schooling data to administrative annual data from the Israeli National Insurance Institute (the equivalent of the social security administration in other countries) spanning the 2000-2014 period. The youngest individuals in our data started high school in 2000, so they were around 31 years old by 2014 . Hence, in our main exercise we focus on educational and labor market outcomes by age 31, which is the latest age at which we are able to observe the youngest individuals in our sample.

\section{a. Post-secondary schooling}

In Table 6, we start by looking at the spillover effects on post-secondary schooling. In columns 1 and 2, we test whether treated peers: (1) were more likely to enroll in any post-secondary schooling at some point from high-school graduation and up to 12 years after high school completion and (2) completed more years of post-secondary schooling up to 12 years since high school graduation. In columns 3 and 4, we repeat the analysis but focusing instead on university enrollment and years of university schooling. In columns 5 and 6 we provide the respective estimates for academic colleges.

On average, peers of early reformers are approximately 10 percentage points more likely to have been enrolled in university schooling 12 years after high school completion. On the intensive margin, students complete 0.53 additional years of university schooling, relative to a mean of around 1.7 years. Note that in the section on high-school outcomes, we found a 9.5 percentage points increase in the probability of obtaining a university-qualified matriculation. When focusing on post-secondary schooling, we find a similar increase in the likelihood of university attendance. This similarity suggests that most of those who obtained a university qualified matriculation indeed enrolled in university education.

The increase in both enrollment and years of university education is accompanied by a shift away from academic colleges. In particular, students are 4 percentage points less likely to enroll in academic colleges and complete 0.12 fewer years of college education. This decrease suggests a shift away from lower into higher quality of post-secondary schooling. As already discussed, for a given field of study, it is typically more difficult to be admitted to a university than to an academic 
college. Moreover, universities offer a premium in the labor market relative to academic colleges (Caplan et al 2009). We note that this result is very different than the direct effect on students from reformed kibbutzim, for whom the post-secondary gain was an increase in academic colleges with zero effect on university schooling. This different pattern of the margin at which we find a positive treatment effect could result from the higher average high school outcomes of the peers relative to the kibbutz students. These higher achievements enable the peers to be admitted to better higher education institutions, in particular universities, and to highly demanded fields of study such as medicine and computer science. Note that, similar to the regressions on high school outcomes and regardless of the specific outcome that we consider, the point estimates barely change as we control for students' background characteristics.

In Panels a) and b) of Figure 1, we measure the treatment effect for each year since high school graduation -starting in year 3 , after students have completed the mandatory military service - and trace the dynamic pattern for each of the post-secondary schooling outcomes. To do so, we run a separate regression for each of the outcomes and for each of the years since high school graduation. We then plot the coefficients of these regressions around a 95\% confidence interval. Note that both the ever-enrolled variable and the years of schooling are cumulative variables. Hence, we expected the effects to be either flat or increasing over time.

We find that the effect on enrollment is flat after five years. This pattern likely reflects the fact that students who do not enroll in post-secondary schooling in the first five years are unlikely to return to school later in life. In contrast, the effect on years of schooling accumulates over time. Although most of the increase happens in the first five years, the effect seems to be increasing even after 12 years since graduation. The fact that the increase keeps accumulating even 12 years after high school graduation suggests that measuring outcomes too close to high-school graduation might underestimate the long-term effects.

The substitution over time from (typically lower quality) academic colleges into (typically higher quality) university can be seen graphically in Panels a) and b) of Figure $1 .{ }^{10}$ The divergence starts early on, suggesting differences in the initial choice of academic institutions and accumulate over time as students spend time in these institutions. By year 12 after high school graduation, students had accumulated 0.5 extra years of university education and 0.12 less years of academic college education.

\section{b. Labor market: employment and earnings in adulthood}

\footnotetext{
${ }^{10}$ Academic colleges in Israel are mainly public teaching (non-research) institutions.
} 
We expect this increase in both the quality and the quantity of education to result in better labor market outcomes in adulthood. In Table 7, we estimate the long-term spillover effects now focusing on labor market outcomes. In column 1, our dependent variable is an indicator that takes a value of one if the individual was employed at least 6 months in a given year. In the second column the dependent variable is the number of months of work in a given year. In the third column, our dependent variable is annual earnings measured in 2009 Israeli NIS. In all columns in this table, we focus on labor market outcomes 12 years after high school graduation.

We find a positive but small and insignificant effect on employment, on either of the two employment measures that we use. The mean employment rate is $85 \%$ in the pre-reform period and it is practically unchanged following the reform. However, we document an increase in annual earnings of about 6988 Israeli New Shekels (NIS)-in 2009 prices -, which is equivalent to $\$ 1742^{11}$, relative to mean earnings of approximately 73,000 NIS. The estimated effect on earnings appears to operate through higher paying jobs because we do not find any effect on employment.

The estimates presented in column 4 show that the spillover effect had lowered the unemployment rate, the duration of unemployment spells and the annual average of unemployment benefits in the treated group. These improvements can be consistent with the zero effect we find on the employment indicators if the duration of unemployment is short enough so that they are not associated with a change in the annual indicators of employment.

In Panels c) and d) of Figure 1, we repeat the year-by-year analysis but now focusing on the two main labor market outcomes (employment and annual earnings). The figure shows the estimated effects by years since graduation from high school. We find an increasing pattern in both employment and earnings. As treated students spent more years on average in the schooling system and appear on average to start working later, we expect the effect on earnings to increase as students accumulate labor market experience. Indeed, we find that the effects are initially small and become significantly different from zero by the end of our sample period. The effects on earnings become significantly different from zero about after 9-11 years from high school graduation, a similar dynamic pattern as in Chetty et al (2016) study on the Moving to Opportunity experiment. Similarly, the effect on employment is initially negative, than it increases for few years and then it levels offs thereafter.

We estimate that students exposed to peers from early reformed kibbutzim increased their years of university education by about 0.5 and decreased their years of college education by 0.12 years. Combining the earnings and years of schooling effects, we can compute the returns to

${ }^{11} 1$ Israeli NIS was worth 0.25 US dollars in 2009. 
schooling that, given the observed increase in schooling, would rationalize the size of the earnings effects. The mean annual earnings 11 years after graduation for individuals in our sample is approximately 73000 Israeli NIS. Hence, an increase of 6988 NIS represents approximately an $9.0 \%$ increase. If the increase in the years of schooling would have been the only channel through which individuals increased their long-term earnings, then the return to a year of university or college education would have needed to be such that: Return*0.54 $=9.0 \%$. Hence, the observed simultaneous increase in earnings and schooling is consistent with a return to one extra year of schooling of $16 \% .^{12}$

This calculation suggests that an important fraction of the increase in earnings was due to the increase in post-secondary educational attainment. However, the improved matriculation outcomes can account for part of the increase in earnings independently of their effect on university years of schooling. Particularly important is the matriculation rate where evidence suggests that a matriculation diploma is rewarded in the labor market by a return beyond its effect on postsecondary schooling. For example, Angrist and Lavy (2009) estimates that bagrut holders earn 13 percent more than other individuals with exactly 12 years of schooling. Similarly, the quality improvements in the matriculation study program, reflected partly by a higher average score, are also rewarded in the labor market beyond their effect on post-secondary schooling (Caplan et al $(2006)){ }^{13}$

\section{c. Alternative specifications and robustness}

In Tables A.10 and A.11, we show that, similar to the results on high school outcomes, the results for university and college schooling and labor market outcomes are similar when controlling for average family income in the regressions. In Table A.12, we show that the results also hold when we estimate aggregate treatment effects using a summary index for post-secondary schooling and labor market outcomes.

A natural question about the above estimated effect on earnings is whether it captures the permanent long-term effects. First, note that we measure the effect on earnings when individuals

\footnotetext{
${ }^{12}$ Recent estimates of the rate of return to a year of university schooling in Israel ranges from 12 to 16 percent. Frish (2009) exploit changes in compulsory schooling laws and obtain IV estimates that are much larger than the OLS Mincerian estimates. Navon (2006) estimate that the return to an MA degree (two years of schooling) is 30 percent.

${ }^{13}$ Caplan et al (2006) demonstrate that earnings in Israel is highly positively correlated with the quality of post-secondary schooling (colleges versus universities and higher versus lower quality universities). For example, this study shows that earnings are much higher for graduates of Tel Aviv, Jerusalem and the Technion Universities relative to graduates from the other four universities in the country. Admission to the top universities is of course positively correlated with the high school matriculation outcomes.
} 
already completed their post-secondary schooling. Second, based on a sample of older cohorts, we find that earnings at age 30-35 is a strong predictor of earnings at an older age. Yet, it is important to note that earnings have larger variation over time than other personal outcomes. To get a better indication about the permanency of the effect on earnings, we estimated the effect on the percentile rank of individuals in the respective distribution of their cohort (at the national level). There is no direct evidence that suggests that rank forecast is more stable than earnings or log earnings. However, recent papers in the intergenerational mobility literature provide some indirect evidence that is relevant to this issue. These studies have shown that movements across ranks in the income distribution are uncorrelated with parental income conditional on rank at age 30; in contrast, movement in log earnings are correlated with parental income conditional on log income at age $30 .{ }^{14}$

Table A.13 in the appendix presents estimates of the effect of the program on percentile rank of earnings, where the rank is computed separately for each cohort based on their percentile in the national income distribution. The estimates are fully consistent with the estimated effects on earnings that are presented in Table 7. After 12 years from high school graduation, the program moves treated individuals by about 4 percentile ranks in the national income distribution.

\section{d. Heterogeneous effects}

Differences between men and women. In Panel (ii) of Table 6 we present the estimated effects on post-secondary schooling outcomes by gender. Clearly the same pattern emerges: higher point estimates for male students, although the gender-specific estimates are not statistically different. The effect on post-secondary years of schooling is twice as large for men (0.61) relative to women (0.30), even though both gender have a similar increase in university years of schooling. However, there is a decline in academic colleges years of schooling (-0.29) for women with no parallel decline for men. This suggest that the gain for women is mainly in the intensive quality of schooling margin without and expansion in the extensive margin.

In Panel (ii) of Table 7, we present the estimated effects on long-term labor market outcomes by gender. The point estimate of the effect on earnings is about twice the size for men than for women, though again the two estimates are not statistically different.

\footnotetext{
14 For example, Nybom and Stuhler (2016) show with data from Sweden that the relationship between a child's income rank and their parental income rank stabilizes by around age 30; in contrast, the relationship in log earnings is less stable. Chetty et al (2016) find a similar pattern in the US tax data, reporting that percentile ranks predict well where children of different economic backgrounds will fall in the income distribution later in life. Using instead log earnings leads to inferior predictions because of the growth path expansions at the top of the income distribution.
} 
Differences by social background of students. The evidence regarding long term postsecondary outcomes in Table 8 (columns 3-4) reveals a contrast between low and high socioeconomic groups that is similar to that between women and men: both groups experienced a similar increase in university years of schooling ( 0.65 and 0.75 , respectively) but for the low mother's education group this improvement was offset by a decline in college years of schooling $(-0.40)$. This suggest that the spillover effects induced disadvantaged students to move from lower to higher level of post-secondary schooling with smaller gains at the extensive schooling margin for this group. We note however that the gain in earnings is larger and more precisely estimated for the low mother's education group though again the high standard error on the estimate for the high mother's education group does not allow us to reject the hypothesis that the two estimates are equal.

\section{Mechanisms}

There are three main channels of social interaction through which the reform could have improved outcomes for peers. First, peers might have benefited because the improvement in kibbutzniks' performance could free up teachers' time. That is, teachers who previously divided their time between kibbutzniks and non-kibbutzniks, would now have more time to spend with nonkibbutzniks, as kibbutzniks started to take school more seriously. Second, the improvement in the schooling performance of kibbutz students might have benefited their peers through conventional peer effects. Finally, the pay reform might have increased the salience of returns to schooling for the peers. While our setting and identification strategy does not enable us to separately identify these three channels of social interaction, we provide suggestive evidence to shed light on which of the channels were likely to have played a more prominent role in explaining our results.

First, our finding that male peers improved their performance more than female peers suggests that freeing up teacher's time is unlikely to be the main explanation for our findings (unless teachers disproportionately spend their extra time on male students). Similarly, we find that the improvement in high school performance was larger among students whose mothers had below median education, which again seems inconsistent with a reallocation of teacher's time being the main channel.

Second, past studies have shown that standard peer effects are relatively small (Angrist 2013), and hence are unlikely to fully explain the effect that we observe in our study. In addition, in a conventional peer effects story we expect the effects to increase with the fraction of early reformers in a grade. To test whether this was the case, we estimated a version of equation (1) in which we replaced the Treated $_{s c}$ indicator with four indicators corresponding to the grade being on each quartile of the distribution of the fraction of early reformers. Table 8 shows the results of 
this exercise. The evidence does not indicate that the effects are increasing on the fraction of early reformers in the grade. Rather, the effects are close to zero in the first quartile but of similar size in the upper three quartiles. We note, however, that we cannot rule out conventional peer effects operating in a non-linear way. Such peer effects could have arisen if early reformers were less likely to interact with their peers as their proportion in the grade increased, a mechanism discussed in Carrell, Sacerdote and West (2013).

The last channel we explore is the effect of transmission of information about the returns to schooling. In our setting, peers are likely to have received first-hand information on the returns to schooling by students from reformed kibbutzim. We expect information to be highly salient in this setting, as many kibbutz students experienced actual declines in their family income. In other words, receiving the information that the family of one of your classmates lost income because of lack of education is likely a powerful incentive to study.

The fact that the effects are similar in size as long as the fraction of early reformers is above a threshold (Table 8) is consistent with information transmission being a driver of our results. This non-linearity in the diffusion of information is described in the model of information diffusion in networks in Banerjee, Chandrasekhar, Duflo and Jackson (2013). In this model, the probability that an individual receives information grows at an exponential rate with the number of initially informed individuals in the network. To illustrate this point formally, assume that there are $n$ directly treated individuals in a grade, and that there is a probability $p$ that each of them shares information with another student. For a given student, the probability of interacting with at least one treated student (the probability of "contagion") will be equal to: $1-(1-p)^{n}$. This expression converges to one at an exponential rate. For instance, if the probability $p$ of interaction is 0.5 , then it only takes 4 directly treated students for the probability of contagion to be above $90 \%$. Futhermore, these effects "snowball" over time, as the first treated peer interacts with a second peer, the second with a third, and so on (Dahl, Løken and Mogstad 2014). In our setting, this snowballing effect can be particularly large because students spend a long period of time together in high-school.

In addition, previous research also suggests that information can have large effects on schooling outcomes. One example is Jensen (2010), who finds that students who were informed about the returns to schooling completed 0.25-0.35 extra years of schooling. Moreover, the spillover effects of information transmission have been shown to be of similar size than the direct effects. For instance, in the Duflo and Saez (2003) article discussed in the introduction, informational spillover effects were about the same size as the effects on directly informed individuals. 
A shared interpretation of the results presented in this paper and in Jensen (2010) and Baker et al (2017) is that students, both outside and inside the kibbutz, may not be well informed about the returns to schooling in the labor market. High schools in Israel typically do not have guidance counselors to provide information about these returns. As a result, students gather information on this matter from what they can observe around them. This information could be both partial and inaccurate, because our sample of peers includes mainly youths in rural communities or small towns where many of the parents are either farmers or independent workers. More precisely, thirty percent of the students in our sample have at least one parent with positive earnings as an independent worker, compared to 4 percent among kibbutzniks and 15 percent among students in other high schools in Israel. Hence, these students may have little information from which to infer the labor market returns to schooling, especially for higher education and in the urban sector. ${ }^{15}$

Given this background, we examine whether the spillover effects are larger among students with at least one parent who works as an independent worker. We present these results in online appendix Table A.14. In column 1 we present the estimated effect on the summary index of high school outcomes. The estimated effect is 70 percent larger for the students whom their father, mother or both have earnings as independent workers, 0.192 (0.072) versus 0.119 (0.064) for students whom both parents are salaried workers (third row of the table). However, this large difference is not estimated precisely enough to be statistically different from zero. In the second column we present the estimated effect on the summary index of post-secondary schooling and labor market outcomes. The estimated effect obtained from the sample of students from families with earnings from independent work is again larger but the difference is smaller and again not statistically different from zero. These findings, though not conclusive, are consistent with our interpretation that the students in our sample are not well informed about the labor market returns to education.

One direct implication of the information transmission mechanism is that peers should not just increase their effort in the intensive margin, but should also redirect their effort towards highschool subjects that are conducive to post-secondary schooling degrees with high financial returns. To test this possibility, we study the extent to which peers increased the number of credit units devoted to English, math and sciences. In Israel, completing five credit units in these subjects (which is equivalent to enrolling in honor level classes in the US) is often required for admission

\footnotetext{
${ }^{15}$ Indeed, the correlation between earnings and schooling is weaker among independent than among salaried workers Using the sample of parents in our study, the estimated coefficients on years of schooling in a Mincerian equation with demographic controls is 8 percent for independent workers versus 12 percent among salaried workers.
} 
to fields of study such as Engineering, Computer Science and Economics, which are among the ones with the highest financial returns in the labor market.

Table 9 shows the results of this exercise. Consistent with students switching towards subjects with relatively high financial returns, the table shows an increase in the number of credit units in Math and English, as well as an increase in the number of science subjects taken in high school and a decrease in the number of non-science subjects. Interestingly, the effect of the reform for high school kibbutzniks is different in terms of field of study. We find (appendix table A.15) that kibbutzniks became more likely to complete enough units required to get a bagrut, especially in non-scientific subjects. This difference could result from the relatively higher average highschool outcomes of the kibbutz students' peers. The lower average achievement of kibbutz students implies that it is less likely that they will expand their enrollment in honor level classes in STEM subjects.

Overall, the combination of these channels resulted in spillover effects that are similar in magnitude to the direct effects, though we note that in both cases the estimated effect on some outcomes are small. In addition to the already discussed article of Duflo and Saez (2003), previous papers have documented spillover effects in other contexts that are of similar magnitude to the effect of those directly exposed to treatment. For instance, Miguel and Kremer (2004) show spillover effect on school peers of similar magnitude to those of students who directly received deworming drugs, demonstrating that deworming creates positive epidemiological externalities. In Angelucci and Di Giorgi (2009) study of the spillover effects of Progresa, the increase in the consumption of the ineligible in treated villages is about half of the increase of directly treated individuals.

\section{Conclusions}

We studied the spillover effects to non-kibbutz members of a reform that increased the returns to schooling of kibbutz students. To do so, we compared the high school and post-secondary schooling outcomes of peers of students from early and late reformed kibbutz, before and after the early reforms. In the short-run, students exposed to early reformers improved their high school outcomes and shifted to courses with potentially higher financial returns. In the long run, these students completed more years of university education and had better labor market outcomes in adulthood. These effects appear to be driven by male students and by students who have less educated parents.

Our results highlight the potentially powerful role of personal and salient information about the returns to schooling. We show that these effects can be persistent in the long run, as some of 
the decisions that students make during school (for instance, studying hard to obtain a matriculation certificate) have important long-run consequences by opening the door to higher education and higher paying occupations. The large response to changes in the (perceived) return to schooling in the Israeli context stands in contrast to the more muted response that has been documented in the US context (Altonji et al 2012). One potential explanation for this difference is that, in the Israeli context, the direct monetary costs of acquiring skills are much lower than in the US, and that these costs have been shown to be an important driver of schooling decisions (Dynarski 2003).

More broadly, the pay reform can be interpreted as a sharp decrease in the marginal tax rate faced by kibbutz members. Such changes might affect both the human capital accumulation of those directly affected and of those not directly affected through spillover effects. For instance, if there are complementarities in production, changes in the tax schedule that affect only some individuals might indirectly affect others. If these spillover effects are economically meaningful as in our case, then estimates of labor supply elasticities that focus solely on individual level responses might underestimate the true burden of taxes. 


\section{References}

1. Abramitzky, R. Lessons from the Kibbutz on the Equality-Incentives Trade-off. The Journal of Economic Perspectives 25, 185-207 (2011).

2. Abramitzky, R. The Mystery of the Kibbutz: Egalitarian Principles in a Capitalist World (Princeton University Press, 2018).

3. Abramitzky, R. \& Lavy, V. How responsive is investment in schooling to changes in redistributive policies and in returns? Econometrica 82, 1241-1272 (2014).

4. Altonji, J. G., Bharadwaj, P. \& Lange, F. Changes in the characteristics of American youth: Implications for adult outcomes. Journal of Labor Economics 30, 783-828 (2012).

5. Angelucci, M. \& De Giorgi, G. Indirect effects of an aid program: how do cash transfers affect ineligibles' consumption? The American Economic Review, 486-508 (2009).

6. Angrist, J. D. The perils of peer effects. Labour Economics 30, 98-108 (2014).

7. Angrist, J. \& Lavy, V. The effects of high stakes high school achievement awards: Evidence from a randomized trial. The American Economic Review 99, 1384-1414 (2009).

8. Baker, R., Bettinger, E., Jacob, B. \& Marinescu, I. The Effect of Labor Market Information on Community College Students' Major Choice tech. rep. (National Bureau of Economic Research, 2017).

9. Banerjee, A., Chandrasekhar, A. G., Duflo, E. \& Jackson, M. O. The diffusion of microfinance. eng. Science (New York, N.Y.) 341, 1236498. ISSN: 1095-9203 (July 2013).

10. Bianchi, N. The Indirect Effects of Educational Expansions: Evidence from a Large Enrollment Increase in STEM Majors. English (US). https://www . scholars . northwestern. edu/en/publications/the-indirect-effects-of-educational-expansionsevidence-from-a-la (2018) (Jan. 2016). 
11. Bobonis, G. J. \& Finan, F. Neighborhood peer effects in secondary school enrollment decisions. The Review of Economics and Statistics 91, 695-716 (2009).

12. Brunello, G., Crivellaro, E. \& Rocco, L. Lost in transition? Economics of Transition 20, 637-676 (2012).

13. Caplan, T., Furman, O., Romanov, D. \& Zussman, N. The quality of Israeli academic institutions: What the wages of graduates tell about it? Samuel Neaman Institution for Advanced Studies in Science and Technology. Haifa, Israel: Technion-Israel Institute of Technology (2006).

14. Carrell, S. E., Sacerdote, B. I. \& West, J. E. From Natural Variation to Optimal Policy? The Importance of Endogenous Peer Group Formation. en. Econometrica 81, 855-882. ISSN: 1468-0262 (May 2013).

15. Chetty, R., Friedman, J. N. \& Rockoff, J. E. Measuring the impacts of teachers II: Teacher value-added and student outcomes in adulthood. The American Economic Review 104, 2633-2679 (2014).

16. Chetty, R., Hendren, N. \& Katz, L. F. The effects of exposure to better neighborhoods on children: New evidence from the Moving to Opportunity experiment. The American Economic Review 106, 855-902 (2016).

17. Chetty, R., Hendren, N., Kline, P. \& Saez, E. Where is the land of Opportunity? The Geography of Intergenerational Mobility in the United States. The Quarterly Journal of Economics 129, 1553-1623 (2014).

18. Crépon, B., Duflo, E., Gurgand, M., Rathelot, R. \& Zamora, P. Do Labor Market Policies have Displacement Effects? Evidence from a Clustered Randomized Experiment*. Quarterly Journal of Economics 128 (2013).

19. Dahl, G. B., Løken, K. V. \& Mogstad, M. Peer Effects in Program Participation. en. American Economic Review 104, 2049-2074. ISSN: 0002-8282 (July 2014). 
20. Duflo, E., Saez, E., et al. The Role of Information and Social Interactions in Retirement Plan Decisions: Evidence from a Randomized Experiment. The Quarterly Journal of Economics 118, 815-842 (2003).

21. Dynarski, S. M. Does aid matter? Measuring the effect of student aid on college attendance and completion. American Economic Review 93, 279-288 (2003).

22. Frish, R. The economic returns to schooling in Israel. Israel Economic Review 7, 113-141 (2009).

23. Hoxby, C. Peer effects in the classroom: Learning from gender and race variation tech. rep. working paper 7867 (National Bureau of Economic Research, 2000).

24. Jensen, R. The (perceived) returns to education and the demand for schooling. Quarterly Journal of Economics 125 (2010).

25. Kling, J. R., Liebman, J. B. \& Katz, L. F. Experimental analysis of neighborhood effects. Econometrica 75, 83-119 (2007).

26. Lalive, R. \& Cattaneo, M. A. Social interactions and schooling decisions. The Review of Economics and Statistics 91, 457-477 (2009).

27. Lavy, V. \& Schlosser, A. Mechanisms and impacts of gender peer effects at school. American Economic Journal: Applied Economics 3, 1-33 (2011).

28. McGuigan, M., McNally, S. \& Wyness, G. Student Awareness of Costs and Benefits of Educational Decisions: Effects of an Information Campaign. Journal of Human Capital 10, 482-519 (2016).

29. Miguel, E. \& Kremer, M. Worms: identifying impacts on education and health in the presence of treatment externalities. Econometrica 72, 159-217 (2004).

30. Navon, G. Human Capital Heterogeneity: University Choice and Wages en. Tech. rep. 9708 (University Library of Munich, Germany, Mar. 2006). https : / / ideas . repec . org/p/pra/mprapa/9708.html (2018). 
31. Nybom, M. \& Stuhler, J. Heterogeneous income profiles and lifecycle bias in intergenerational mobility estimation. Journal of Human Resources 51, 239-268 (2016). 
Table 1: Sample Size

\begin{tabular}{lcccccc}
\hline \hline & \multicolumn{2}{c}{ Full } & \multicolumn{2}{c}{ Treated } & \multicolumn{2}{c}{ Control } \\
& Before & After & Before & After & Before & After \\
\hline $\begin{array}{l}\text { Number of Schools } \\
\text { Number of Grades (school/years) }\end{array}$ & 31 & 31 &. &. &. &. \\
$\quad \begin{array}{l}\text { Number of Students } \\
\quad \text { I. Peers }\end{array}$ & 3177 & 4529 & 2052 & 3379 & 1125 & 110 \\
$\quad$ II. Kibbutzniks & & & & & & \\
$\quad$ i. Early reformers & 999 & 905 & 999 & 905 & 0 & 0 \\
$\quad$ ii. Late reformers & 502 & 487 & 390 & 400 & 112 & 87 \\
\hline
\end{tabular}

Note: This table shows the number of schools and number of treatment and control grades in our baseline sample. A grade (school/year combination) is defined as treated if it includes students from early reformed kibbutzim. 
Table 2: Descriptive Statistics, Balancing and Post-Treatment Differences

\begin{tabular}{|c|c|c|c|c|c|c|c|c|}
\hline & \multicolumn{4}{|c|}{ 10th Grade Students in 1995 and 1996} & \multicolumn{4}{|c|}{ 10th Grade Students in 1999 and 2000} \\
\hline & $\begin{array}{c}\text { Full } \\
\text { (1) }\end{array}$ & $\begin{array}{c}\text { Treatment } \\
\text { (2) }\end{array}$ & $\begin{array}{c}\text { Control } \\
\text { (3) }\end{array}$ & $\begin{array}{c}\text { Difference } \\
\text { (4) }\end{array}$ & $\begin{array}{c}\text { Full } \\
(5)\end{array}$ & $\begin{array}{c}\text { Treatment } \\
\text { (6) }\end{array}$ & $\begin{array}{c}\text { Control } \\
\text { (7) }\end{array}$ & $\begin{array}{c}\text { Difference } \\
(8)\end{array}$ \\
\hline \multicolumn{9}{|l|}{ A. Background characteristics } \\
\hline \multirow[t]{2}{*}{ Male Indicator } & 0.512 & 0.499 & 0.536 & -0.036 & 0.507 & 0.505 & 0.512 & -0.010 \\
\hline & $(0.500)$ & $(0.500)$ & $(0.499)$ & $(0.018)$ & $(0.500)$ & $(0.500)$ & $(0.500)$ & $(0.021)$ \\
\hline \multirow[t]{2}{*}{ Father Years of Schooling } & 13.449 & 13.683 & 13.022 & 0.658 & 13.653 & 13.753 & 13.358 & 0.392 \\
\hline & $(3.459)$ & $(3.251)$ & $(3.773)$ & $(0.559)$ & $(3.459)$ & $(3.096)$ & $(3.554)$ & $(0.506)$ \\
\hline \multirow[t]{2}{*}{ Mother Years of Schooling } & 13.523 & 13.735 & 13.136 & 0.604 & 13.926 & 14.060 & 13.535 & 0.535 \\
\hline & $(3.114)$ & $(2.964)$ & $(3.336)$ & $(0.385)$ & (3.114) & $(2.893)$ & $(3.231)$ & $(0.402)$ \\
\hline \multirow[t]{2}{*}{ Number of Siblings } & 2.449 & 2.374 & 2.587 & -0.213 & 2.300 & 2.321 & 2.238 & 0.086 \\
\hline & $(1.361)$ & $(1.213)$ & $(1.587)$ & $(0.329)$ & $(1.361)$ & $(1.165)$ & $(1.134)$ & $(0.129)$ \\
\hline \multirow[t]{2}{*}{ Asia-Africa Ethnicity } & 0.212 & 0.195 & 0.244 & -0.050 & 0.184 & 0.176 & 0.209 & -0.036 \\
\hline & $(0.409)$ & $(0.396)$ & $(0.429)$ & $(0.063)$ & $(0.409)$ & $(0.381)$ & $(0.407)$ & $(0.061)$ \\
\hline \multirow[t]{2}{*}{ Europe-America Ethnicity } & 0.213 & 0.225 & 0.192 & 0.032 & 0.192 & 0.201 & 0.166 & 0.033 \\
\hline & $(0.410)$ & $(0.418)$ & $(0.394)$ & $(0.023)$ & $(0.410)$ & $(0.401)$ & $(0.372)$ & $(0.018)$ \\
\hline \multirow[t]{2}{*}{ Other Ethnicity } & 0.005 & 0.004 & 0.008 & -0.004 & 0.009 & 0.010 & 0.006 & 0.005 \\
\hline & $(0.073)$ & $(0.062)$ & $(0.089)$ & $(0.003)$ & $(0.073)$ & $(0.100)$ & $(0.078)$ & $(0.004)$ \\
\hline \multirow[t]{2}{*}{ Former Soviet Union Ethnicity } & 0.053 & 0.047 & 0.064 & -0.018 & 0.056 & 0.056 & 0.055 & 0.004 \\
\hline & $(0.224)$ & $(0.211)$ & $(0.245)$ & $(0.038)$ & $(0.224)$ & $(0.230)$ & $(0.228)$ & $(0.018)$ \\
\hline \multirow[t]{2}{*}{ Ethiopia Ethnicity } & 0.007 & 0.002 & 0.015 & -0.012 & 0.017 & 0.012 & 0.032 & -0.019 \\
\hline & $(0.083)$ & $(0.049)$ & $(0.122)$ & $(0.007)$ & $(0.083)$ & $(0.108)$ & $(0.177)$ & $(0.016)$ \\
\hline \multirow[t]{2}{*}{ Family Income } & 24.117 & 23.322 & 25.674 & -2.404 & 24.018 & 23.965 & 24.179 & -0.156 \\
\hline & $(24.898)$ & $(24.716)$ & $(25.191)$ & $(3.808)$ & $(20.952)$ & $(20.841)$ & $(21.295)$ & (3.399) \\
\hline \multicolumn{9}{|l|}{ B. High School Outcomes } \\
\hline \multirow[t]{2}{*}{ High School Completion } & 0.955 & 0.953 & 0.960 & -0.007 & 0.961 & 0.962 & 0.958 & 0.003 \\
\hline & $(0.207)$ & $(0.212)$ & $(0.196)$ & $(0.013)$ & $(0.207)$ & $(0.190)$ & $(0.200)$ & $(0.009)$ \\
\hline \multirow[t]{2}{*}{ Mean Matriculation Score } & 70.892 & 71.150 & 70.421 & 0.777 & 74.010 & 74.665 & 72.084 & 2.551 \\
\hline & (21.609) & $(21.711)$ & $(21.423)$ & $(1.851)$ & (21.609) & ( 19.830) & ( 19.977$)$ & $(0.961)$ \\
\hline \multirow[t]{2}{*}{ Matriculation Certification } & 0.616 & 0.616 & 0.614 & 0.002 & 0.687 & 0.707 & 0.630 & 0.076 \\
\hline & $(0.487)$ & $(0.486)$ & $(0.487)$ & $(0.051)$ & $(0.487)$ & $(0.455)$ & $(0.483)$ & $(0.038)$ \\
\hline \multirow[t]{2}{*}{ University Qualified Matriculation } & 0.575 & 0.578 & 0.570 & 0.009 & 0.632 & 0.654 & 0.568 & 0.088 \\
\hline & $(0.494)$ & $(0.494)$ & $(0.495)$ & $(0.057)$ & $(0.494)$ & $(0.476)$ & $(0.496)$ & $(0.050)$ \\
\hline Observations & 3177 & 2052 & 1125 & & 4529 & 3379 & 1150 & \\
\hline
\end{tabular}




\begin{tabular}{|c|c|c|c|c|c|c|c|c|}
\hline & \multicolumn{4}{|c|}{ 10th Grade Students in 1995 and 1996} & \multicolumn{4}{|c|}{ 10th Grade Students in 1999 and 2000} \\
\hline & $\begin{array}{l}\text { Full } \\
\text { (1) }\end{array}$ & $\begin{array}{c}\text { Treatment } \\
\text { (2) }\end{array}$ & $\begin{array}{l}\text { Control } \\
\text { (3) }\end{array}$ & $\begin{array}{c}\text { Difference } \\
\text { (4) }\end{array}$ & $\begin{array}{l}\text { Full } \\
(5)\end{array}$ & $\begin{array}{l}\text { Treatment } \\
\text { (6) }\end{array}$ & $\begin{array}{l}\text { Control } \\
\text { (7) }\end{array}$ & $\begin{array}{c}\text { Difference } \\
\text { (8) }\end{array}$ \\
\hline \multicolumn{9}{|l|}{ C. Post-secondary education } \\
\hline Post-secondary years of schooling & $\begin{array}{c}2.969 \\
(2.539)\end{array}$ & $\begin{array}{c}2.928 \\
(2.543)\end{array}$ & $\begin{array}{c}3.045 \\
(2.531)\end{array}$ & $\begin{array}{l}-0.124 \\
(0.344)\end{array}$ & $\begin{array}{c}2.958 \\
(2.464)\end{array}$ & $\begin{array}{c}2.996 \\
(2.471)\end{array}$ & $\begin{array}{c}2.843 \\
(2.438)\end{array}$ & $\begin{array}{c}0.162 \\
(0.215)\end{array}$ \\
\hline Post-secondary Enrollment & $\begin{array}{c}0.705 \\
(0.456)\end{array}$ & $\begin{array}{c}0.695 \\
(0.461)\end{array}$ & $\begin{array}{c}0.724 \\
(0.447)\end{array}$ & $\begin{array}{l}-0.030 \\
(0.049)\end{array}$ & $\begin{array}{c}0.713 \\
(0.452)\end{array}$ & $\begin{array}{c}0.719 \\
(0.450)\end{array}$ & $\begin{array}{c}0.696 \\
(0.460)\end{array}$ & $\begin{array}{c}0.023 \\
(0.044)\end{array}$ \\
\hline University years of schooling & $\begin{array}{c}1.554 \\
(2.426)\end{array}$ & $\begin{array}{l}1.478 \\
(2.381)\end{array}$ & $\begin{array}{l}1.698 \\
(2.503)\end{array}$ & $\begin{array}{l}-0.236 \\
(0.303)\end{array}$ & $\begin{array}{l}1.400 \\
(2.273)\end{array}$ & $\begin{array}{c}1.448 \\
(2.299)\end{array}$ & $\begin{array}{l}1.253 \\
(2.187)\end{array}$ & $\begin{array}{c}0.215 \\
(0.181)\end{array}$ \\
\hline University Enrollment & $\begin{array}{c}0.366 \\
(0.482)\end{array}$ & $\begin{array}{c}0.348 \\
(0.477)\end{array}$ & $\begin{array}{c}0.399 \\
(0.490)\end{array}$ & $\begin{array}{l}-0.054 \\
(0.067)\end{array}$ & $\begin{array}{c}0.345 \\
(0.475)\end{array}$ & $\begin{array}{c}0.354 \\
(0.478)\end{array}$ & $\begin{array}{c}0.319 \\
(0.466)\end{array}$ & $\begin{array}{c}0.039 \\
(0.049)\end{array}$ \\
\hline College years of schooling & $\begin{array}{c}0.981 \\
(1.625)\end{array}$ & $\begin{array}{l}1.015 \\
(1.654)\end{array}$ & $\begin{array}{c}0.917 \\
(1.567)\end{array}$ & $\begin{array}{c}0.103 \\
(0.078)\end{array}$ & $\begin{array}{l}1.141 \\
(1.668)\end{array}$ & $\begin{array}{l}1.141 \\
(1.672)\end{array}$ & $\begin{array}{l}1.140 \\
(1.656)\end{array}$ & $\begin{array}{c}0.002 \\
(0.118)\end{array}$ \\
\hline College Enrollment & $\begin{array}{c}0.332 \\
(0.471)\end{array}$ & $\begin{array}{c}0.342 \\
(0.475)\end{array}$ & $\begin{array}{c}0.313 \\
(0.464)\end{array}$ & $\begin{array}{c}0.031 \\
(0.023)\end{array}$ & $\begin{array}{c}0.390 \\
(0.488)\end{array}$ & $\begin{array}{c}0.391 \\
(0.488)\end{array}$ & $\begin{array}{c}0.388 \\
(0.488)\end{array}$ & $\begin{array}{c}0.003 \\
(0.032)\end{array}$ \\
\hline \multicolumn{9}{|l|}{ D. Labor market } \\
\hline Employment & $\begin{array}{c}0.775 \\
(0.418)\end{array}$ & $\begin{array}{c}0.767 \\
(0.423)\end{array}$ & $\begin{array}{c}0.789 \\
(0.408)\end{array}$ & $\begin{array}{l}-0.021 \\
(0.015)\end{array}$ & $\begin{array}{c}0.793 \\
(0.405)\end{array}$ & $\begin{array}{c}0.790 \\
(0.407)\end{array}$ & $\begin{array}{c}0.801 \\
(0.400)\end{array}$ & $\begin{array}{l}-0.005 \\
(0.012)\end{array}$ \\
\hline Annual earnings & $\begin{array}{c}7.787 \\
(7.719)\end{array}$ & $\begin{array}{c}7.636 \\
(7.960)\end{array}$ & $\begin{array}{c}8.075 \\
(7.233)\end{array}$ & $\begin{array}{l}-0.451 \\
(0.459)\end{array}$ & $\begin{array}{c}7.728 \\
(7.135)\end{array}$ & $\begin{array}{c}7.769 \\
(7.078)\end{array}$ & $\begin{array}{c}7.602 \\
(7.304)\end{array}$ & $\begin{array}{c}0.303 \\
(0.519)\end{array}$ \\
\hline Unempyomnet indicator & $\begin{array}{c}0.063 \\
(0.243)\end{array}$ & $\begin{array}{c}0.067 \\
(0.249)\end{array}$ & $\begin{array}{c}0.056 \\
(0.231)\end{array}$ & $\begin{array}{c}0.010 \\
(0.007)\end{array}$ & $\begin{array}{c}0.052 \\
(0.222)\end{array}$ & $\begin{array}{c}0.051 \\
(0.221)\end{array}$ & $\begin{array}{c}0.055 \\
(0.227)\end{array}$ & $\begin{array}{l}-0.006 \\
(0.010)\end{array}$ \\
\hline Number of months of UI benefits & $\begin{array}{c}0.207 \\
(0.896)\end{array}$ & $\begin{array}{c}0.229 \\
(0.961)\end{array}$ & $\begin{array}{c}0.164 \\
(0.754)\end{array}$ & $\begin{array}{c}0.067 \\
(0.030)\end{array}$ & $\begin{array}{c}0.172 \\
(0.818)\end{array}$ & $\begin{array}{c}0.167 \\
(0.803)\end{array}$ & $\begin{array}{c}0.186 \\
(0.862)\end{array}$ & $\begin{array}{l}-0.033 \\
(0.047)\end{array}$ \\
\hline Total unemployment benefits & $\begin{array}{c}861.025 \\
(3924.410)\end{array}$ & $\begin{array}{c}941.263 \\
(4135.073)\end{array}$ & $\begin{array}{c}708.420 \\
(3485.447)\end{array}$ & $\begin{array}{c}241.263 \\
(125.897)\end{array}$ & $\begin{array}{c}576.043 \\
(2949.807)\end{array}$ & $\begin{array}{c}567.320 \\
(2931.195)\end{array}$ & $\begin{array}{c}602.229 \\
(3006.102)\end{array}$ & $\begin{array}{c}-88.927 \\
(156.030)\end{array}$ \\
\hline Observations & 3177 & 2052 & 1125 & & 4529 & 3379 & 1150 & \\
\hline
\end{tabular}

Note: Columns 1 and 5 present means and standard deviations (in parentheses) of background characteristics and outcomes of students before and after the early reforms. Columns 2, 3, 6 and 7 present the means and standard deviations for students in treatment and control grades for affected (1999-2000) and unaffected (1995-1996) cohorts of 10th graders. Columns 4 and 8 present the differences between treatment and control grades, controlling for cohort fixed effects. Family income and annual earnings are in ten thousands NIS. Standard errors of these differences clustered at the school level are given in parentheses. 
Table 3: Pre-Reform Time Trends, 10th Grade Students from 1994 to 1997

\begin{tabular}{lccccc}
\hline \hline & $\begin{array}{c}\text { High School } \\
\text { Completion }\end{array}$ & $\begin{array}{c}\text { Mean } \\
\text { Matriculation } \\
\text { Score } \\
(1)\end{array}$ & $\begin{array}{c}\text { Matriculation } \\
\text { Certification }\end{array}$ & $\begin{array}{c}\text { University Qualified } \\
\text { Matriculation }\end{array}$ & $\begin{array}{c}\text { Summary } \\
\text { Index }\end{array}$ \\
& $(2)$ & $(3)$ & $(4)$ & $(5)$ \\
\hline i. Simple diff-in-diff $(\mathrm{N}=6178)$ & & & & \\
Treatment $\times 1995$ & -0.017 & -0.198 & 0.009 & -0.004 & -0.020 \\
& $(0.028)$ & $(5.610)$ & $(0.065)$ & $(0.056)$ & $(0.155)$ \\
Treatment $\times 1996$ & -0.030 & -2.369 & 0.015 & -0.010 & -0.060 \\
& $(0.019)$ & $(3.557)$ & $(0.032)$ & $(0.025)$ & $(0.081)$ \\
Treatment $\times 1997$ & -0.021 & -0.647 & 0.048 & 0.015 & -0.000 \\
& $(0.019)$ & $(3.713)$ & $(0.051)$ & $(0.051)$ & $(0.109)$ \\
$F$-statistic & 0.790 & 0.939 & 0.840 & 0.293 & 0.769 \\
$p$-value & 0.381 & 0.630 & 0.668 & 0.922 & 0.690 \\
ii. Controlled diff-in-diff $(\mathrm{N}=6178)$ & & & & -0.005 & -0.017 \\
Treatment $\times 1995$ & -0.014 & -0.061 & 0.007 & $(0.050)$ & $(0.150)$ \\
& $(0.028)$ & $(5.572)$ & $(0.062)$ & -0.006 & -0.054 \\
Treatment $\times 1996$ & -0.027 & -2.408 & 0.018 & $(0.031)$ & $(0.099)$ \\
& $(0.02)$ & $(4.121)$ & $(0.039)$ & 0.021 & 0.020 \\
Treatment $\times 1997$ & -0.014 & -0.112 & 0.053 & $(0.041)$ & $(0.104)$ \\
& $(0.020)$ & $(3.765)$ & $(0.046)$ & 0.293 & 0.769 \\
$F$-statistic & 0.790 & 0.939 & 0.840 & 0.830 & 0.521 \\
$p$-value & 0.509 & 0.434 & 0.483 & & \\
\hline
\end{tabular}

Note: This table presents the results from OLS regressions for the cohorts of 10th graders from 1994 to 1997 (pre reform), in which the difference in high-school outcomes between treatment and control grades is allowed to vary for each cohort of students. The F-statistics test whether all the interaction terms between treatment indicators and the cohorts dummy variables are jointly zero. The dependent variable in column 1 is an indicator of whether the student completed high school; in column 2 it is her mean score in the matriculation exams; in column 3 it is an indicator of whether she received a matriculation certificate; in column 4 it is an indicator of whether she received a matriculation certificate that satisfies the requirements for university study; in column 5 is the summary index based on the outcomes in columns 1 to 4 . A grade (school/year combination) is defined as treated if it includes students from early reformed kibbutzim. The simple difference-in-differences regressions include only cohort dummies and school fixed effects, as well the interactions terms between cohort dummies and the treatment indicator. The controlled difference-in-differences also includes the following students demographic controls: gender, father's and mother's education, number of siblings, a set of ethnic dummies (origin from Africa/Asia, Europe/America, immigrants from FSU, Ethiopia and other countries). Standard errors clustered at the school level are presented in parentheses. 
Table 4: Short-Term Effects on High-School Outcomes

\begin{tabular}{|c|c|c|c|c|c|}
\hline & $\begin{array}{c}\text { High School } \\
\text { Completion } \\
(1) \\
\end{array}$ & $\begin{array}{c}\text { Mean } \\
\text { Matriculation } \\
\text { Score } \\
(2)\end{array}$ & $\begin{array}{c}\text { Matriculation } \\
\text { Certification } \\
\text { (3) }\end{array}$ & $\begin{array}{c}\text { University } \\
\text { Qualified } \\
\text { Matriculation } \\
\text { (4) }\end{array}$ & $\begin{array}{c}\text { Sum- } \\
\text { mary } \\
\text { Index } \\
(5)\end{array}$ \\
\hline \multicolumn{6}{|l|}{ A. Short-Term Effects } \\
\hline Treated X After & $\begin{array}{c}0.016 \\
(0.009)\end{array}$ & $\begin{array}{c}2.387 \\
(2.001)\end{array}$ & $\begin{array}{c}0.078 \\
(0.033)\end{array}$ & $\begin{array}{l}0.083 \\
(0.031)\end{array}$ & $\begin{array}{c}0.135 \\
(0.064)\end{array}$ \\
\hline \multicolumn{6}{|l|}{ ii. Controlled diff-in-diff $(\mathrm{N}=7706)$} \\
\hline Treated X After & $\begin{array}{c}0.018 \\
(0.008)\end{array}$ & $\begin{array}{c}2.759 \\
(1.838)\end{array}$ & $\begin{array}{c}0.088 \\
(0.030)\end{array}$ & $\begin{array}{c}0.094 \\
(0.029)\end{array}$ & $\begin{array}{c}0.153 \\
(0.058)\end{array}$ \\
\hline \multicolumn{6}{|l|}{ iii. Cross-sectional regression } \\
\hline Treatment-control diff., before $(\mathrm{N}=3177)$ & $\begin{array}{l}-0.007 \\
(0.013)\end{array}$ & $\begin{array}{c}0.777 \\
(1.851)\end{array}$ & $\begin{array}{c}0.002 \\
(0.051)\end{array}$ & $\begin{array}{c}0.009 \\
(0.057)\end{array}$ & $\begin{array}{c}0.006 \\
(0.087)\end{array}$ \\
\hline Treatment-control diff., after $(\mathrm{N}=4529)$ & $\begin{array}{c}0.003 \\
(0.009)\end{array}$ & $\begin{array}{l}2.551 \\
(0.961)\end{array}$ & $\begin{array}{c}0.076 \\
(0.038)\end{array}$ & $\begin{array}{c}0.088 \\
(0.050)\end{array}$ & $\begin{array}{c}0.122 \\
(0.065)\end{array}$ \\
\hline \multicolumn{6}{|l|}{$\begin{array}{l}\text { B. Placebo Timing } \\
\text { i. Simple diff-in-diff }(\mathrm{N}=5424)\end{array}$} \\
\hline Treated X After & $\begin{array}{l}-0.012 \\
(0.014)\end{array}$ & $\begin{array}{c}-0.785 \\
(1.651)\end{array}$ & $\begin{array}{c}0.018 \\
(0.033)\end{array}$ & $\begin{array}{l}0.005 \\
(0.023)\end{array}$ & $\begin{array}{c}-0.012 \\
(0.061)\end{array}$ \\
\hline $\begin{array}{l}\text { ii. Controlled diff-in-diff }(\mathrm{N}=5424) \\
\text { Treated X After }\end{array}$ & $\begin{array}{l}-0.007 \\
(0.013)\end{array}$ & $\begin{array}{c}-0.306 \\
(1.534)\end{array}$ & $\begin{array}{l}0.026 \\
(0.031)\end{array}$ & $\begin{array}{c}0.013 \\
(0.021)\end{array}$ & $\begin{array}{c}0.007 \\
(0.055)\end{array}$ \\
\hline
\end{tabular}

Note: The dependent variable in column 1 is an indicator of whether the student completed high school; in column 2 it is her mean score in the matriculation exams; in column 3 it is an indicator of whether she received a matriculation certificate; in column 4 it is an indicator of whether she received a matriculation certificate that satisfies the requirements for university study; in column 5 is the summary index based on the outcomes in columns 1 to 4 . In Panel A, the sample includes all the students (excluding kibbutzim members themselves) who attended schools with a positive number of either early or late reformed kibbutzim residents in both the before (1995/1996) and the after (1999/2000) periods. The first two rows of Panel A presents the estimated coefficients of interest in difference-in-differences regressions, comparing students in treated and untreated grades who are treated (10th grade in 1999/2000) and untreated (10th grade in 1995/1996). A grade (school/year combination) is defined as treated if it includes students from early reformed kibbutzim. The simple difference-in-differences regressions include only cohort dummies and school fixed effects. The second panel of the table shows the controlled difference-in-differences, which also includes the following students demographic controls: gender, father's and mother's education, number of siblings, a set of ethnic dummies (origin from Africa/Asia, Europe/America, immigrants from FSU, Ethiopia and other countries). The third row of Panel A shows the estimated effects using only the before (1995/1996) cohorts and using only the after (1999/2000) cohorts. Panel B reports the results of a placebo experiment in which we assume the early reforms happened in 1996 instead of 1998. We then use data from 1994-1995 and 1996-1997 to compare treated to control grades, before (1994-1995) and after (1996-1997) the placebo reforms. Standard errors clustered at the school level and presented in parentheses. 
Table 5: Short-Term Effects on High-School Outcomes, by Gender and Mother's Education

\begin{tabular}{|c|c|c|c|c|c|}
\hline & $\begin{array}{c}\text { High School } \\
\text { Completion } \\
\text { (1) }\end{array}$ & $\begin{array}{c}\text { Mean } \\
\text { Matriculation } \\
\text { Score } \\
\text { (2) }\end{array}$ & $\begin{array}{c}\text { Matriculation } \\
\text { Certification } \\
\text { (3) }\end{array}$ & $\begin{array}{c}\text { University } \\
\text { Qualified } \\
\text { Matriculation } \\
\text { (4) }\end{array}$ & $\begin{array}{l}\text { Summary- } \\
\text { Index } \\
\text { (5) }\end{array}$ \\
\hline \multicolumn{6}{|c|}{ i. Stratification by gender } \\
\hline Male $(\mathrm{N}=3203)$ & $\begin{array}{c}0.036 \\
(0.022)\end{array}$ & $\begin{array}{c}5.261 \\
(2.254)\end{array}$ & $\begin{array}{c}0.123 \\
(0.037)\end{array}$ & $\begin{array}{c}0.102 \\
(0.037)\end{array}$ & $\begin{array}{c}0.224 \\
(0.074)\end{array}$ \\
\hline Female $(\mathrm{N}=3141)$ & $\begin{array}{c}0.000 \\
(0.016)\end{array}$ & $\begin{array}{c}-2.035 \\
(1.374)\end{array}$ & $\begin{array}{c}0.038 \\
(0.039)\end{array}$ & $\begin{array}{c}0.052 \\
(0.045)\end{array}$ & $\begin{array}{c}0.021 \\
(0.052)\end{array}$ \\
\hline $\mathrm{p}$-value & 0.302 & 0.000 & 0.009 & 0.358 & 0.000 \\
\hline \multicolumn{6}{|c|}{ ii. Stratification by mother's education } \\
\hline Low $(\mathrm{N}=2540)$ & $\begin{array}{c}0.027 \\
(0.017)\end{array}$ & $\begin{array}{c}3.056 \\
(2.036)\end{array}$ & $\begin{array}{c}0.105 \\
(0.049)\end{array}$ & $\begin{array}{c}0.102 \\
(0.047)\end{array}$ & $\begin{array}{c}0.176 \\
(0.076)\end{array}$ \\
\hline $\operatorname{High}(\mathrm{N}=3804)$ & $\begin{array}{c}0.011 \\
(0.012)\end{array}$ & $\begin{array}{c}0.443 \\
(1.617)\end{array}$ & $\begin{array}{c}0.052 \\
(0.032)\end{array}$ & $\begin{array}{c}0.048 \\
(0.028)\end{array}$ & $\begin{array}{c}0.071 \\
(0.053)\end{array}$ \\
\hline $\mathrm{p}$-value & 0.530 & 0.193 & 0.260 & 0.166 & 0.127 \\
\hline
\end{tabular}

Note: This table presents the same results as in table 4 but estimated separately for males and females (panel i) and for low and high mother's education (panel ii). We also report the p-value corresponding to the null hypothesis that the effects are the same in both subsamples. The sample includes students that have at least 6 peers in a grade from reformed kibbutzim. 
Table 6: Long-Term Effects on Post-Secondary Schooling Outcomes

\begin{tabular}{|c|c|c|c|c|c|c|}
\hline & \multicolumn{2}{|c|}{ All post secondary } & \multicolumn{2}{|c|}{ University } & \multicolumn{2}{|c|}{ College } \\
\hline & $\begin{array}{l}\text { Enroll- } \\
\text { ment } \\
(1)\end{array}$ & $\begin{array}{l}\text { Years of } \\
\text { schooling } \\
\text { (2) }\end{array}$ & $\begin{array}{c}\text { Enroll- } \\
\text { ment } \\
(3)\end{array}$ & $\begin{array}{l}\text { Years of } \\
\text { schooling } \\
\text { (4) }\end{array}$ & $\begin{array}{c}\text { Enroll- } \\
\text { ment } \\
(5)\end{array}$ & $\begin{array}{c}\text { Years of } \\
\text { schooling } \\
\text { (6) }\end{array}$ \\
\hline \multicolumn{7}{|l|}{ i. Full sample $(\mathrm{N}=7555)$} \\
\hline Simple diff-in-diff & $\begin{array}{c}0.040 \\
(0.021)\end{array}$ & $\begin{array}{c}0.235 \\
(0.191)\end{array}$ & $\begin{array}{c}0.087 \\
(0.034)\end{array}$ & $\begin{array}{c}0.487 \\
(0.183)\end{array}$ & $\begin{array}{c}-0.043 \\
(0.036)\end{array}$ & $\begin{array}{l}-0.165 \\
(0.113)\end{array}$ \\
\hline Controlled diff-in-diff & $\begin{array}{c}0.045 \\
(0.020)\end{array}$ & $\begin{array}{c}0.279 \\
(0.183)\end{array}$ & $\begin{array}{c}0.094 \\
(0.034)\end{array}$ & $\begin{array}{c}0.527 \\
(0.182)\end{array}$ & $\begin{array}{c}-0.043 \\
(0.037)\end{array}$ & $\begin{array}{c}-0.164 \\
(0.117)\end{array}$ \\
\hline \multicolumn{7}{|l|}{ ii. Stratification by gender } \\
\hline Male $(\mathrm{N}=3154)$ & $\begin{array}{c}0.070 \\
(0.031)\end{array}$ & $\begin{array}{c}0.575 \\
(0.231)\end{array}$ & $\begin{array}{c}0.133 \\
(0.040)\end{array}$ & $\begin{array}{c}0.807 \\
(0.206)\end{array}$ & $\begin{array}{c}-0.092 \\
(0.059)\end{array}$ & $\begin{array}{c}-0.239 \\
(0.165)\end{array}$ \\
\hline Female $(\mathrm{N}=3077)$ & $\begin{array}{c}-0.008 \\
(0.037)\end{array}$ & $\begin{array}{c}0.163 \\
(0.272)\end{array}$ & $\begin{array}{c}0.078 \\
(0.051)\end{array}$ & $\begin{array}{c}0.597 \\
(0.189)\end{array}$ & $\begin{array}{c}-0.090 \\
(0.042)\end{array}$ & $\begin{array}{c}-0.391 \\
(0.134)\end{array}$ \\
\hline p-value & 0.079 & 0.113 & 0.341 & 0.157 & 0.976 & 0.239 \\
\hline \multicolumn{7}{|c|}{ iii. Stratification by mother's education } \\
\hline Low $(\mathrm{N}=3223)$ & $\begin{array}{l}-0.025 \\
(0.031)\end{array}$ & $\begin{array}{c}0.079 \\
(0.251)\end{array}$ & $\begin{array}{c}0.088 \\
(0.031)\end{array}$ & $\begin{array}{c}0.637 \\
(0.205)\end{array}$ & $\begin{array}{c}-0.167 \\
(0.051)\end{array}$ & $\begin{array}{l}-0.555 \\
(0.160)\end{array}$ \\
\hline $\operatorname{High}(\mathrm{N}=3008)$ & $\begin{array}{c}0.082 \\
(0.024)\end{array}$ & $\begin{array}{c}0.658 \\
(0.192)\end{array}$ & $\begin{array}{c}0.125 \\
(0.041)\end{array}$ & $\begin{array}{c}0.791 \\
(0.169)\end{array}$ & $\begin{array}{c}-0.006 \\
(0.032)\end{array}$ & $\begin{array}{c}-0.031 \\
(0.129)\end{array}$ \\
\hline p-value & 0.001 & 0.001 & 0.187 & 0.349 & 0.000 & 0.001 \\
\hline
\end{tabular}

Note: The dependent variables in columns 1 and 2 are an indicator whether a student ever enrolled in any post-secondary education, and the total years of schooling in any post-secondary education 13 years after high-school graduation; In columns 3 and 4 these are an indicator whether a student ever enrolled in a university, and total years of schooling in university 13 years after high-school graduation; In columns 5 and 6 the dependent variables are an indicator whether a student ever enrolled in a college, and total years of schooling in college 13 years after high-school graduation; The full sample includes students that have at least 2 peers in a grade from reformed kibbutzim, and the stratified samples include students that have at least 6 peers in a grade from reformed kibbutzim. We also report the p-value corresponding to the null hypothesis that the effects are the same in both subsamples. Standard errors clustered at the school level and presented in parentheses. 
Table 7: Long-Term Effects on Labor Market Outcomes

\begin{tabular}{|c|c|c|c|c|c|c|}
\hline & \multicolumn{3}{|c|}{ Labor market } & \multicolumn{3}{|c|}{ Unemployment benefits } \\
\hline & $\begin{array}{c}\text { Employ- } \\
\text { ment } \\
(1)\end{array}$ & $\begin{array}{l}\text { Work- } \\
\text { months } \\
(2)\end{array}$ & $\begin{array}{c}\text { Earn- } \\
\text { ings } \\
(3)\end{array}$ & $\begin{array}{l}\text { Unemployed } \\
\text { indicator } \\
(4)\end{array}$ & $\begin{array}{c}\text { Total } \\
\text { benefits } \\
(5)\end{array}$ & $\begin{array}{l}\text { Number of } \\
\text { months } \\
(6)\end{array}$ \\
\hline \multicolumn{7}{|l|}{ i. Full sample $(\mathrm{N}=7546)$} \\
\hline Simple diff-in-diff & $\begin{array}{c}0.022 \\
(0.016)\end{array}$ & $\begin{array}{c}0.277 \\
(0.209)\end{array}$ & $\begin{array}{l}7614.4 \\
(3536.5)\end{array}$ & $\begin{array}{l}-0.014 \\
(0.009)\end{array}$ & $\begin{array}{c}-293.2 \\
(132.4)\end{array}$ & $\begin{array}{l}-0.089 \\
(0.039)\end{array}$ \\
\hline Controlled diff-in-diff & $\begin{array}{c}0.027 \\
(0.016)\end{array}$ & $\begin{array}{c}0.322 \\
(0.223)\end{array}$ & $\begin{array}{l}6988.8 \\
(3518.5)\end{array}$ & $\begin{array}{l}-0.015 \\
(0.009)\end{array}$ & $\begin{array}{c}-309.2 \\
(134.6)\end{array}$ & $\begin{array}{l}-0.089 \\
(0.040)\end{array}$ \\
\hline \multicolumn{7}{|l|}{ ii. Stratification by gender } \\
\hline Male $(\mathrm{N}=3151)$ & $\begin{array}{c}0.056 \\
(0.020)\end{array}$ & $\begin{array}{c}0.720 \\
(0.210)\end{array}$ & $\begin{array}{l}11326.8 \\
(7512.3)\end{array}$ & $\begin{array}{l}-0.008 \\
(0.010)\end{array}$ & $\begin{array}{l}-148.0 \\
(174.2)\end{array}$ & $\begin{array}{l}-0.053 \\
(0.033)\end{array}$ \\
\hline Female $(\mathrm{N}=3072$ ) & $\begin{array}{l}-0.007 \\
(0.022)\end{array}$ & $\begin{array}{c}0.027 \\
(0.301)\end{array}$ & $\begin{array}{l}5315.5 \\
(5564.1)\end{array}$ & $\begin{array}{l}-0.013 \\
(0.013)\end{array}$ & $\begin{array}{l}-291.0 \\
(331.6)\end{array}$ & $\begin{array}{l}-0.081 \\
(0.075)\end{array}$ \\
\hline p-value & 0.004 & 0.027 & 0.606 & 0.833 & 0.748 & 0.761 \\
\hline \multicolumn{7}{|c|}{ iii. Stratification by mother's education } \\
\hline Low $(\mathrm{N}=3219)$ & $\begin{array}{l}-0.010 \\
(0.028)\end{array}$ & $\begin{array}{l}-0.140 \\
(0.326)\end{array}$ & $\begin{array}{l}5814.3 \\
(4362.9)\end{array}$ & $\begin{array}{c}0.002 \\
(0.008)\end{array}$ & $\begin{array}{c}-89.9 \\
(168.2)\end{array}$ & $\begin{array}{l}-0.063 \\
(0.047)\end{array}$ \\
\hline High $(\mathrm{N}=3004)$ & $\begin{array}{c}0.074 \\
(0.021)\end{array}$ & $\begin{array}{c}1.067 \\
(0.209)\end{array}$ & $\begin{array}{l}11304.8 \\
(4656.5)\end{array}$ & $\begin{array}{l}-0.025 \\
(0.011)\end{array}$ & $\begin{array}{c}-397.3 \\
(204.9)\end{array}$ & $\begin{array}{l}-0.071 \\
(0.045)\end{array}$ \\
\hline $\mathrm{p}$-value & 0.016 & 0.002 & 0.384 & 0.065 & 0.184 & 0.874 \\
\hline
\end{tabular}

Note: The dependent variables in columns 1,2 and 3 are an indicator of whether the student was in the labor force, number of work months and her annual earnings in 2009 Israeli NIS 12 years after high-school graduation; In columns 4, 5 and 6 these are an indicator whether the student is entitled to unemployment benefits, number of months receiving unemployment benefits and total unemployment benefits in 2009 Israeli NIS in year 2012; The full sample includes students that have at least 2 peers in a grade from reformed kibbutzim and the stratified samples include students that have at least 6 peers in grade from reformed kibbutzim. We also report the p-value corresponding to the null hypothesis that the effects are the same in both subsamples. Standard errors clustered at the school level and presented in parentheses. 
Table 8: Short-Term Effects on High-School Outcomes, by Intensity of Exposure

\begin{tabular}{|c|c|c|c|c|c|}
\hline & $\begin{array}{c}\text { High School } \\
\text { Completion } \\
\text { (1) }\end{array}$ & $\begin{array}{c}\text { Mean } \\
\text { Matriculation } \\
\text { Score } \\
(2)\end{array}$ & $\begin{array}{c}\text { Matriculation } \\
\text { Certification } \\
\text { (3) }\end{array}$ & $\begin{array}{l}\text { University Qualified } \\
\text { Matriculation } \\
\text { (4) }\end{array}$ & $\begin{array}{l}\text { Summary } \\
\text { Index } \\
\text { (5) }\end{array}$ \\
\hline \multicolumn{6}{|c|}{ i. Simple diff-in-diff $(N=7706)$} \\
\hline 1st quartile $\mathrm{X}$ after & $\begin{array}{c}0.003 \\
(0.013)\end{array}$ & $\begin{array}{c}1.008 \\
(3.220)\end{array}$ & $\begin{array}{c}0.029 \\
(0.060)\end{array}$ & $\begin{array}{c}0.050 \\
(0.053)\end{array}$ & $\begin{array}{c}0.056 \\
(0.104)\end{array}$ \\
\hline 2nd quartile $\mathrm{X}$ after & $\begin{array}{c}0.010 \\
(0.012)\end{array}$ & $\begin{array}{c}3.080 \\
(2.428)\end{array}$ & $\begin{array}{c}0.130 \\
(0.059)\end{array}$ & $\begin{array}{c}0.128 \\
(0.055)\end{array}$ & $\begin{array}{c}0.181 \\
(0.096)\end{array}$ \\
\hline 3rd quartile $\mathrm{X}$ after & $\begin{array}{c}0.026 \\
(0.018)\end{array}$ & $\begin{array}{c}3.262 \\
(2.515)\end{array}$ & $\begin{array}{c}0.041 \\
(0.035)\end{array}$ & $\begin{array}{c}0.052 \\
(0.035)\end{array}$ & $\begin{array}{c}0.120 \\
(0.076)\end{array}$ \\
\hline 4th quartile $X$ after & $\begin{array}{c}0.029 \\
(0.011)\end{array}$ & $\begin{array}{c}1.243 \\
(2.517)\end{array}$ & $\begin{array}{c}0.065 \\
(0.035)\end{array}$ & $\begin{array}{c}0.057 \\
(0.038)\end{array}$ & $\begin{array}{c}0.114 \\
(0.075)\end{array}$ \\
\hline \multicolumn{6}{|c|}{ ii. Controlled diff-in-diff $(\mathrm{N}=7706)$} \\
\hline 1st quartile $\mathrm{X}$ after & $\begin{array}{c}0.008 \\
(0.013)\end{array}$ & $\begin{array}{l}1.808 \\
(2.870)\end{array}$ & $\begin{array}{c}0.049 \\
(0.050)\end{array}$ & $\begin{array}{c}0.071 \\
(0.043)\end{array}$ & $\begin{array}{c}0.093 \\
(0.089)\end{array}$ \\
\hline 2nd quartile $\mathrm{X}$ after & $\begin{array}{c}0.011 \\
(0.010)\end{array}$ & $\begin{array}{c}3.459 \\
(1.922)\end{array}$ & $\begin{array}{c}0.142 \\
(0.044)\end{array}$ & $\begin{array}{c}0.141 \\
(0.041)\end{array}$ & $\begin{array}{c}0.200 \\
(0.071)\end{array}$ \\
\hline 3rd quartile $\mathrm{X}$ after & $\begin{array}{c}0.026 \\
(0.019)\end{array}$ & $\begin{array}{c}3.636 \\
(2.601)\end{array}$ & $\begin{array}{c}0.057 \\
(0.033)\end{array}$ & $\begin{array}{c}0.068 \\
(0.033)\end{array}$ & $\begin{array}{c}0.140 \\
(0.079)\end{array}$ \\
\hline 4th quartile $X$ after & $\begin{array}{c}0.029 \\
(0.012)\end{array}$ & $\begin{array}{c}1.144 \\
(2.374)\end{array}$ & $\begin{array}{c}0.063 \\
(0.032)\end{array}$ & $\begin{array}{c}0.053 \\
(0.035)\end{array}$ & $\begin{array}{c}0.110 \\
(0.071)\end{array}$ \\
\hline Mean dependent variable & 0.955 & 70.892 & 0.616 & 0.575 & -0.009 \\
\hline
\end{tabular}

Note: The dependent variables in this table are the same as in table 4. We replace the treatment indicator with four dummies corresponding to quartiles of the share of early reformers on the grade. Each rows corresponds to the estimated coefficient of interest in a difference-in-differences regression.

Table 9: Short-Term Effects on Type of Subjects Taken in High School

\begin{tabular}{|c|c|c|c|c|c|c|}
\hline & $\begin{array}{l}\text { \# of Credit } \\
\text { Units } \\
\text { Received in } \\
\text { Bagrut } \\
\text { (1) }\end{array}$ & $\begin{array}{c}\text { \# of } \\
\text { Credit } \\
\text { Units in } \\
\text { English } \\
\text { (2) }\end{array}$ & $\begin{array}{l}\text { \# of } \\
\text { Credit } \\
\text { Units in } \\
\text { Math } \\
\text { (3) }\end{array}$ & $\begin{array}{c}\# \text { of } \\
\text { Subjects } \\
\text { in High } \\
\text { School } \\
\text { (4) }\end{array}$ & $\begin{array}{c}\# \text { of } \\
\text { Non-Science } \\
\text { Subjects in } \\
\text { High School } \\
\text { (5) }\end{array}$ & $\begin{array}{c}\text { \# of Science } \\
\text { Subjects in } \\
\text { High School } \\
\text { (6) }\end{array}$ \\
\hline \multicolumn{7}{|c|}{ i. Simple diff-in-diff $(\mathrm{N}=7435)$} \\
\hline Treated X After & $\begin{array}{c}1.722 \\
(0.795)\end{array}$ & $\begin{array}{c}0.128 \\
(0.038)\end{array}$ & $\begin{array}{c}0.241 \\
(0.097)\end{array}$ & $\begin{array}{c}0.593 \\
(0.276)\end{array}$ & $\begin{array}{c}-0.175 \\
(0.161)\end{array}$ & $\begin{array}{c}0.768 \\
(0.305)\end{array}$ \\
\hline \multicolumn{7}{|c|}{ ii. Controlled diff-in-diff $(\mathrm{N}=7435)$} \\
\hline Treated X After & $\begin{array}{c}1.845 \\
(0.748)\end{array}$ & $\begin{array}{c}0.155 \\
(0.035)\end{array}$ & $\begin{array}{c}0.261 \\
(0.083)\end{array}$ & $\begin{array}{c}0.616 \\
(0.256)\end{array}$ & $\begin{array}{c}-0.205 \\
(0.175)\end{array}$ & $\begin{array}{c}0.821 \\
(0.293)\end{array}$ \\
\hline Mean dependent variable & 23.045 & 4.215 & 3.190 & 8.001 & 4.642 & 3.359 \\
\hline
\end{tabular}

Note: The first panel of the table presents the estimated coefficients of interest in difference-in-differences regressions, comparing students in treated and untreated grades who are treated (10th grade in 1999/2000) and untreated (10th grade in 1995/1996). A grade (school/year combination) is defined as treated if it includes students from early reformed kibbutzim. The simple difference-indifferences regressions include only cohort dummies and school fixed effects. The second panel of the table shows the controlled difference-in-differences, which also includes the following students demographic controls: gender, father's and mother's education, number of siblings, a set of ethnic dummies (origin from Africa/Asia, Europe/America, immigrants from FSU, Ethiopia and other countries). 
Figure 1: Long term effects on post-secondary schooling and labor market outcomes, by years since graduation

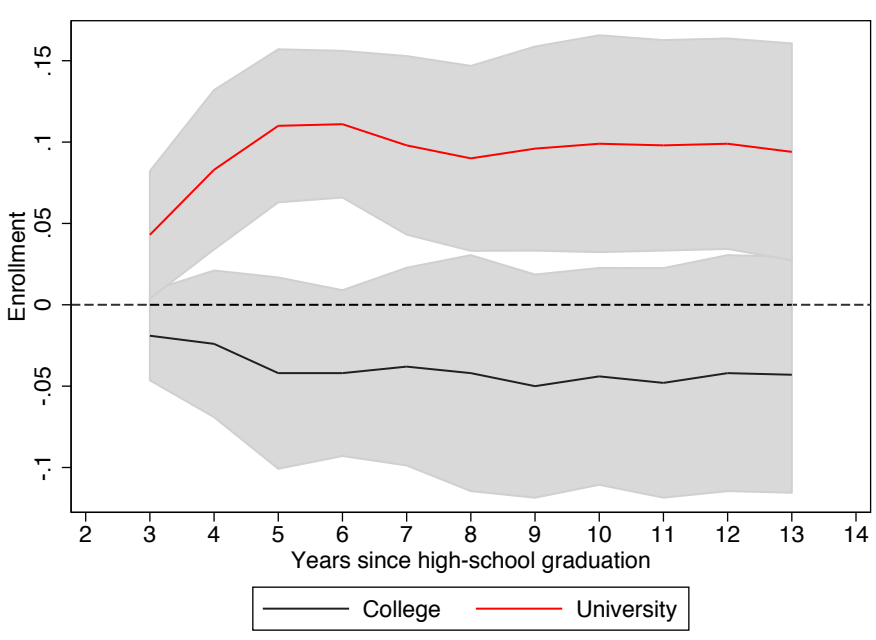

(a) Enrollment

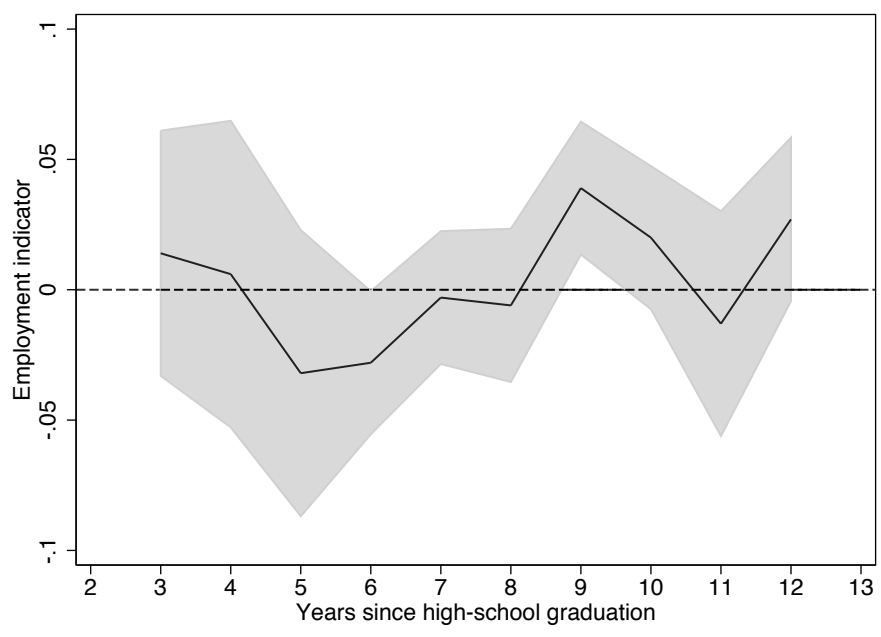

(c) Employment indicator

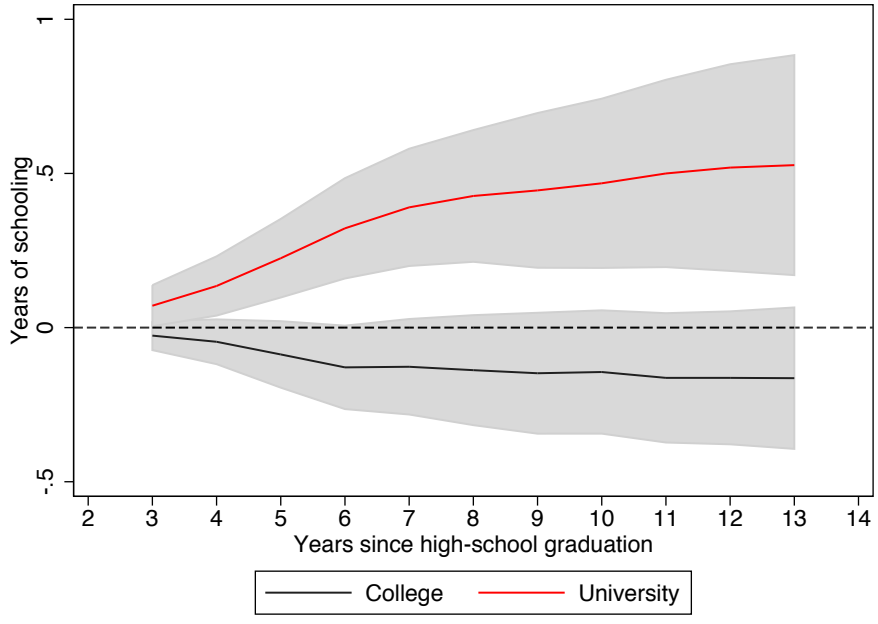

(b) Years of schooling

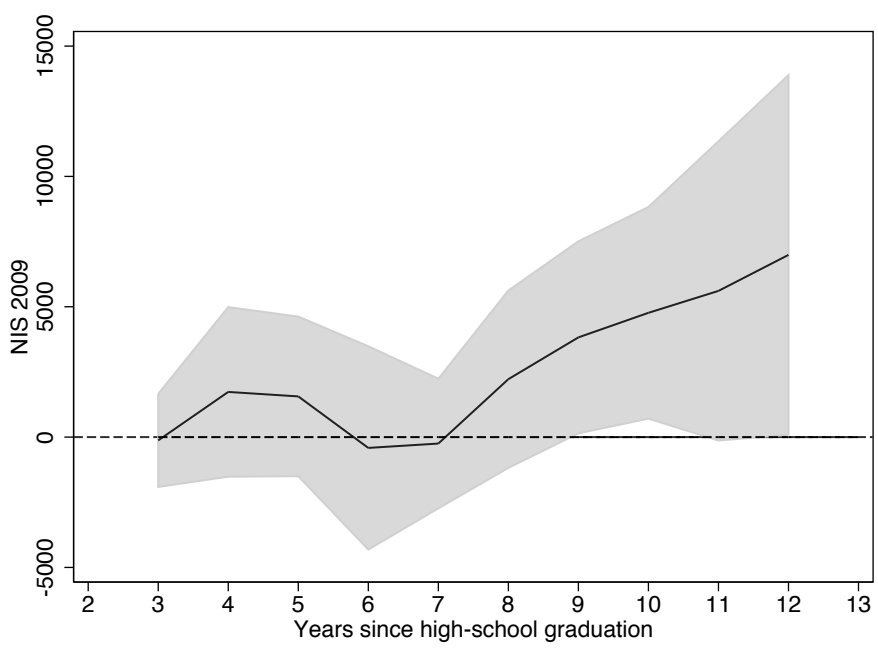

(d) Annual earnings

Note: We plot the estimated effects from 3 to 13 years after high-school graduation. The dependent variable on panel (a) is an indicator that takes a value of one if the student was ever enrolled in post-secondary schooling by the corresponding year. The dependent variable in panel (b) is the years of post-secondary schooling completed by the corresponding year. The dependent variable on panel (c) is an indicator that takes a value of one if the student was part of the labor force in the corresponding year. The dependent variable in panel (d) are annual earnings in 2009 Israeli NIS in the corresponding year. 


\section{Online Appendix - Not for publication}

Table A1: No Change in Background Characteristics of Peers as a Result of the Reform

\begin{tabular}{lc}
\hline \hline & $\begin{array}{c}\text { Treated X after } \\
(1)\end{array}$ \\
\hline i. Full Sample (N=7706) & 0.029 \\
Male Indicator & $(0.030)$ \\
& -0.174 \\
Father Years of Schooling & $(0.180)$ \\
& 0.018 \\
Mother Years of Schooling & $(0.201)$ \\
& 0.378 \\
Number of Siblings & $(0.385)$ \\
& 0.009 \\
Europe-America Ethnicity & $(0.017)$ \\
& 0.010 \\
Other Ethnicity & $(0.005)$ \\
& 0.001 \\
Former Soviet Union Ethnicity & $(0.017)$ \\
& -0.015 \\
Ethiopia Ethnicity & $(0.011)$ \\
& 20.593 \\
Family income & $(10.245)$ \\
& \\
\hline
\end{tabular}

Note: Each row corresponds to a separate regression for each of the student's background characteristics on an interaction between the treatment indicator and an indicator corresponding to cohorts who started school after the early reforms (1999/2000), as described in the main text. 
Table A2: Descriptive Statistics, Balancing and Post-Treatment Differences. Never Reformers

\begin{tabular}{|c|c|c|c|c|c|c|c|c|}
\hline & \multicolumn{4}{|c|}{ 10th Grade Students in 1995 and 1996} & \multicolumn{4}{|c|}{ 10th Grade Students in 1999 and 2000} \\
\hline & $\begin{array}{l}\text { Full } \\
\text { (1) }\end{array}$ & $\begin{array}{l}\text { Treatment } \\
\text { (2) }\end{array}$ & $\begin{array}{l}\text { Control } \\
\text { (3) }\end{array}$ & $\begin{array}{c}\text { Difference } \\
\text { (4) }\end{array}$ & $\begin{array}{l}\text { Full } \\
(5)\end{array}$ & $\begin{array}{c}\text { Treatment } \\
\text { (6) }\end{array}$ & $\begin{array}{c}\text { Control } \\
\text { (7) }\end{array}$ & $\begin{array}{c}\text { Difference } \\
\text { (8) }\end{array}$ \\
\hline \multicolumn{9}{|l|}{ A. Student's characteristics } \\
\hline Male Indicator & $\begin{array}{c}0.509 \\
(0.500)\end{array}$ & $\begin{array}{c}0.503 \\
(0.500)\end{array}$ & $\begin{array}{c}0.526 \\
(0.500)\end{array}$ & $\begin{array}{l}-0.022 \\
(0.022)\end{array}$ & $\begin{array}{c}0.509 \\
(0.500)\end{array}$ & $\begin{array}{c}0.510 \\
(0.500)\end{array}$ & $\begin{array}{c}0.502 \\
(0.500)\end{array}$ & $\begin{array}{c}0.007 \\
(0.029)\end{array}$ \\
\hline Father Years of Schooling & $\begin{array}{c}13.579 \\
(3.473)\end{array}$ & $\begin{array}{c}13.693 \\
(3.240)\end{array}$ & $\begin{array}{c}13.228 \\
(4.090)\end{array}$ & $\begin{array}{c}0.464 \\
(0.711)\end{array}$ & $\begin{array}{c}13.842 \\
(3.473)\end{array}$ & $\begin{array}{c}13.838 \\
(3.094)\end{array}$ & $\begin{array}{c}13.863 \\
(3.500)\end{array}$ & $\begin{array}{c}-0.028 \\
(0.561)\end{array}$ \\
\hline Mother Years of Schooling & $\begin{array}{r}13.650 \\
(3.111)\end{array}$ & $\begin{array}{l}13.740 \\
(2.950)\end{array}$ & $\begin{array}{c}13.374 \\
(3.552)\end{array}$ & $\begin{array}{c}0.364 \\
(0.382)\end{array}$ & $\begin{array}{c}14.126 \\
(3.111)\end{array}$ & $\begin{array}{c}14.147 \\
(2.861)\end{array}$ & $\begin{array}{c}14.014 \\
(3.187)\end{array}$ & $\begin{array}{c}0.132 \\
(0.398)\end{array}$ \\
\hline Number of Siblings & $\begin{array}{c}2.349 \\
(1.288)\end{array}$ & $\begin{array}{c}2.394 \\
(1.253)\end{array}$ & $\begin{array}{c}2.211 \\
(1.384)\end{array}$ & $\begin{array}{c}0.182 \\
(0.132)\end{array}$ & $\begin{array}{c}2.292 \\
(1.288)\end{array}$ & $\begin{array}{c}2.310 \\
(1.170)\end{array}$ & $\begin{array}{c}2.202 \\
(1.069)\end{array}$ & $\begin{array}{c}0.109 \\
(0.115)\end{array}$ \\
\hline Asia-Africa Ethnicity & $\begin{array}{c}0.220 \\
(0.414)\end{array}$ & $\begin{array}{c}0.196 \\
(0.397)\end{array}$ & $\begin{array}{l}0.296 \\
(0.457)\end{array}$ & $\begin{array}{l}-0.101 \\
(0.060)\end{array}$ & $\begin{array}{c}0.191 \\
(0.414)\end{array}$ & $\begin{array}{c}0.174 \\
(0.379)\end{array}$ & $\begin{array}{c}0.282 \\
(0.450)\end{array}$ & $\begin{array}{c}-0.108 \\
(0.057)\end{array}$ \\
\hline Europe-America Ethnicity & $\begin{array}{c}0.219 \\
(0.414)\end{array}$ & $\begin{array}{c}0.226 \\
(0.418)\end{array}$ & $\begin{array}{c}0.197 \\
(0.398)\end{array}$ & $\begin{array}{c}0.029 \\
(0.028)\end{array}$ & $\begin{array}{c}0.201 \\
(0.414)\end{array}$ & $\begin{array}{c}0.204 \\
(0.403)\end{array}$ & $\begin{array}{c}0.185 \\
(0.389)\end{array}$ & $\begin{array}{c}0.018 \\
(0.014)\end{array}$ \\
\hline Other Ethnicity & $\begin{array}{l}0.005 \\
(0.071)\end{array}$ & $\begin{array}{c}0.004 \\
(0.061)\end{array}$ & $\begin{array}{c}0.009 \\
(0.093)\end{array}$ & $\begin{array}{l}-0.005 \\
(0.003)\end{array}$ & $\begin{array}{l}0.010 \\
(0.071)\end{array}$ & $\begin{array}{c}0.010 \\
(0.102)\end{array}$ & $\begin{array}{c}0.010 \\
(0.098)\end{array}$ & $\begin{array}{c}0.001 \\
(0.006)\end{array}$ \\
\hline Former Soviet Union Ethnicity & $\begin{array}{c}0.055 \\
(0.227)\end{array}$ & $\begin{array}{c}0.048 \\
(0.214)\end{array}$ & $\begin{array}{c}0.074 \\
(0.263)\end{array}$ & $\begin{array}{l}-0.026 \\
(0.056)\end{array}$ & $\begin{array}{c}0.061 \\
(0.227)\end{array}$ & $\begin{array}{c}0.059 \\
(0.235)\end{array}$ & $\begin{array}{c}0.071 \\
(0.257)\end{array}$ & $\begin{array}{c}-0.011 \\
(0.034)\end{array}$ \\
\hline Ethiopia Ethnicity & $\begin{array}{c}0.007 \\
(0.082)\end{array}$ & $\begin{array}{c}0.002 \\
(0.049)\end{array}$ & $\begin{array}{c}0.020 \\
(0.142)\end{array}$ & $\begin{array}{l}-0.018 \\
(0.015)\end{array}$ & $\begin{array}{c}0.015 \\
(0.082)\end{array}$ & $\begin{array}{c}0.013 \\
(0.112)\end{array}$ & $\begin{array}{c}0.027 \\
(0.163)\end{array}$ & $\begin{array}{c}-0.014 \\
(0.022)\end{array}$ \\
\hline \multicolumn{9}{|l|}{ B. High School Outcomes } \\
\hline High School Completion & $\begin{array}{c}0.954 \\
(0.210)\end{array}$ & $\begin{array}{c}0.953 \\
(0.212)\end{array}$ & $\begin{array}{c}0.957 \\
(0.203)\end{array}$ & $\begin{array}{c}-0.004 \\
(0.021)\end{array}$ & $\begin{array}{c}0.965 \\
(0.210)\end{array}$ & $\begin{array}{c}0.964 \\
(0.187)\end{array}$ & $\begin{array}{c}0.969 \\
(0.173)\end{array}$ & $\begin{array}{c}-0.006 \\
(0.008)\end{array}$ \\
\hline Mean Matriculation Score & $\begin{array}{c}70.767 \\
(21.356)\end{array}$ & $\begin{array}{c}71.135 \\
(21.724)\end{array}$ & $\begin{array}{c}69.645 \\
(20.165)\end{array}$ & $\begin{array}{c}1.469 \\
(2.015)\end{array}$ & $\begin{array}{c}74.585 \\
(21.356)\end{array}$ & $\begin{array}{c}74.831 \\
(19.555)\end{array}$ & $\begin{array}{c}73.302 \\
(17.886)\end{array}$ & $\begin{array}{c}1.514 \\
(0.872)\end{array}$ \\
\hline Matriculation Certification & $\begin{array}{c}0.623 \\
(0.485)\end{array}$ & $\begin{array}{l}0.617 \\
(0.486)\end{array}$ & $\begin{array}{c}0.642 \\
(0.480)\end{array}$ & $\begin{array}{l}-0.025 \\
(0.057)\end{array}$ & $\begin{array}{l}0.702 \\
(0.485)\end{array}$ & $\begin{array}{l}0.707 \\
(0.455)\end{array}$ & $\begin{array}{c}0.676 \\
(0.468)\end{array}$ & $\begin{array}{c}0.031 \\
(0.032)\end{array}$ \\
\hline University Qualified Matriculation & $\begin{array}{c}0.586 \\
(0.493)\end{array}$ & $\begin{array}{c}0.580 \\
(0.494)\end{array}$ & $\begin{array}{c}0.605 \\
(0.489)\end{array}$ & $\begin{array}{l}-0.025 \\
(0.064)\end{array}$ & $\begin{array}{c}0.653 \\
(0.493)\end{array}$ & $\begin{array}{c}0.656 \\
(0.475)\end{array}$ & $\begin{array}{c}0.636 \\
(0.481)\end{array}$ & $\begin{array}{c}0.019 \\
(0.039)\end{array}$ \\
\hline Observations & 2738 & 2062 & 676 & & 3831 & 3215 & 616 & \\
\hline
\end{tabular}

Note: Columns 1 and 5 present means and standard deviations (in parentheses) of characteristics and outcomes of students before and after the early reforms. Columns 2, 3, 6 and 7 present the means and standard deviations for students in treatment and control grades for affected (19992000) and unaffected (1995-1996) cohorts of 10th graders. Columns 4 and 8 present the differences between treatment and control grades, controlling for cohort fixed effects. Standard errors of these differences clustered at the school level are given in parentheses. 
Table A3: Short-Term Effects on High-School Outcomes, Controlling for Family Income

\begin{tabular}{|c|c|c|c|c|c|}
\hline & $\begin{array}{c}\text { High School } \\
\text { Completion } \\
(1) \\
\end{array}$ & $\begin{array}{c}\text { Mean } \\
\text { Matriculation } \\
\text { Score } \\
(2) \\
\end{array}$ & $\begin{array}{c}\text { Matriculation } \\
\text { Certification } \\
\text { (3) }\end{array}$ & $\begin{array}{c}\text { University } \\
\text { Qualified } \\
\text { Matriculation } \\
\text { (4) }\end{array}$ & $\begin{array}{c}\text { Sum- } \\
\text { mary } \\
\text { Index } \\
(5)\end{array}$ \\
\hline \multicolumn{6}{|l|}{ i. Simple diff-in-diff $(\mathrm{N}=7178)$} \\
\hline Treated X After & $\begin{array}{c}0.016 \\
(0.009)\end{array}$ & $\begin{array}{c}2.387 \\
(2.001)\end{array}$ & $\begin{array}{c}0.078 \\
(0.033)\end{array}$ & $\begin{array}{c}0.083 \\
(0.031)\end{array}$ & $\begin{array}{c}0.131 \\
(0.062)\end{array}$ \\
\hline \multicolumn{6}{|l|}{ ii. Controlled diff-in-diff $(\mathrm{N}=7178)$} \\
\hline Treated X After & $\begin{array}{c}0.020 \\
(0.009)\end{array}$ & $\begin{array}{c}2.695 \\
(1.997)\end{array}$ & $\begin{array}{c}0.077 \\
(0.032)\end{array}$ & $\begin{array}{c}0.079 \\
(0.030)\end{array}$ & $\begin{array}{c}0.137 \\
(0.061)\end{array}$ \\
\hline \multicolumn{6}{|l|}{ iii. Cross-sectional regression } \\
\hline Treatment-control diff., before $(\mathrm{N}=2956)$ & $\begin{array}{c}-0.007 \\
(0.013)\end{array}$ & $\begin{array}{c}0.777 \\
(1.851)\end{array}$ & $\begin{array}{c}0.002 \\
(0.051)\end{array}$ & $\begin{array}{c}0.009 \\
(0.057)\end{array}$ & $\begin{array}{c}0.006 \\
(0.085)\end{array}$ \\
\hline Treatment-control diff., after $(\mathrm{N}=4222)$ & $\begin{array}{c}0.003 \\
(0.009)\end{array}$ & $\begin{array}{c}2.551 \\
(0.961) \\
\end{array}$ & $\begin{array}{c}0.076 \\
(0.038) \\
\end{array}$ & $\begin{array}{c}0.088 \\
(0.050) \\
\end{array}$ & $\begin{array}{c}0.118 \\
(0.063) \\
\end{array}$ \\
\hline Mean dependent variable & 0.955 & 70.892 & 0.616 & 0.575 & -0.009 \\
\hline
\end{tabular}

Note: This table replicates the results in Table 4 adding family income as an additional control variable. Sample is restricted to students whose parents had no missing earnings data.

Table A4: Short-Term Effects on High-school Outcomes. No School Fixed Effects

\begin{tabular}{lccccc}
\hline \hline & $\begin{array}{c}\text { High School } \\
\text { Completion }\end{array}$ & $\begin{array}{c}\text { Mean } \\
\text { Matriculation } \\
\text { Score } \\
(1)\end{array}$ & $\begin{array}{c}\text { Matriculation } \\
\text { Certification }\end{array}$ & $\begin{array}{c}\text { University Qualified } \\
\text { Matriculation }\end{array}$ & $\begin{array}{c}\text { Summary } \\
\text { Index }\end{array}$ \\
& $(1)$ & $(3)$ & $(4)$ & $(5)$ \\
\hline i. Full Sample (N=7698) & & & & & \\
Simple diff-in-diff & 0.010 & 1.774 & 0.075 & 0.079 & 0.113 \\
& $(0.011)$ & $(1.953)$ & $(0.034)$ & $(0.033)$ & $(0.064)$ \\
Controlled diff-in-diff & 0.015 & 2.391 & 0.089 & 0.097 & 0.142 \\
& $(0.009)$ & $(1.772)$ & $(0.029)$ & $(0.029)$ & $(0.054)$ \\
\hline
\end{tabular}

Note: This table replicates the results in table 4 without including school fixed effects to the regression. 
Table A5: Short-Term Effects on High-School Outcomes, by Minimum Number of Peers from Reformed Kibbutzim

\begin{tabular}{|c|c|c|c|c|c|}
\hline & $\begin{array}{c}\text { High School } \\
\text { Completion } \\
\text { (1) }\end{array}$ & $\begin{array}{c}\text { Mean } \\
\text { Matriculation } \\
\text { Score } \\
(2)\end{array}$ & $\begin{array}{c}\text { Matriculation } \\
\text { Certification } \\
\text { (3) }\end{array}$ & $\begin{array}{c}\text { University } \\
\text { Qualified } \\
\text { Matriculation } \\
\text { (4) }\end{array}$ & $\begin{array}{l}\text { Sum- } \\
\text { mary } \\
\text { Index } \\
(5)\end{array}$ \\
\hline \multicolumn{6}{|l|}{ A. At least 3 kibbutzniks } \\
\hline Treated X After & $\begin{array}{c}0.019 \\
(0.009)\end{array}$ & $\begin{array}{c}3.244 \\
(2.071)\end{array}$ & $\begin{array}{c}0.086 \\
(0.034)\end{array}$ & $\begin{array}{c}0.090 \\
(0.032)\end{array}$ & $\begin{array}{c}0.158 \\
(0.066)\end{array}$ \\
\hline \multicolumn{6}{|c|}{ ii. Controlled diff-in-diff $(\mathrm{N}=7138)$} \\
\hline Treated X After & $\begin{array}{c}0.021 \\
(0.009)\end{array}$ & $\begin{array}{c}3.597 \\
(1.892)\end{array}$ & $\begin{array}{c}0.096 \\
(0.029)\end{array}$ & $\begin{array}{c}0.100 \\
(0.030)\end{array}$ & $\begin{array}{c}0.175 \\
(0.060)\end{array}$ \\
\hline Mean dependent variable & 0.956 & 71.097 & 0.622 & 0.582 & -0.078 \\
\hline \multicolumn{6}{|l|}{ B. At least 6 kibbutzniks } \\
\hline Treated X After & $\begin{array}{c}0.016 \\
(0.009)\end{array}$ & $\begin{array}{c}1.285 \\
(1.815)\end{array}$ & $\begin{array}{c}0.073 \\
(0.039)\end{array}$ & $\begin{array}{c}0.073 \\
(0.035)\end{array}$ & $\begin{array}{c}0.113 \\
(0.068)\end{array}$ \\
\hline \multicolumn{6}{|c|}{ ii. Controlled diff-in-diff $(\mathrm{N}=6352)$} \\
\hline Treated X After & $\begin{array}{c}0.018 \\
(0.009)\end{array}$ & $\begin{array}{c}1.661 \\
(1.635)\end{array}$ & $\begin{array}{c}0.079 \\
(0.035)\end{array}$ & $\begin{array}{c}0.077 \\
(0.032)\end{array}$ & $\begin{array}{c}0.126 \\
(0.061)\end{array}$ \\
\hline Mean dependent variable & 0.953 & 70.664 & 0.620 & 0.583 & -0.086 \\
\hline
\end{tabular}

Note: This table replicates the results in Table 4 using two alternative samples. In the first panel, the sample is restricted to grades with at least 3 students from reformed kibbutzim. In the second panel, the sample is restricted to grades with at least 6 students from reformed kibbutzim.

Table A6: Short-Term Effects on High-School Outcomes, Instrumental Variables Model

\begin{tabular}{lccccc}
\hline \hline & $\begin{array}{c}\text { High School } \\
\text { Completion }\end{array}$ & $\begin{array}{c}\text { Mean } \\
\text { Matriculation } \\
\text { Score } \\
(1)\end{array}$ & $\begin{array}{c}\text { Matriculation } \\
\text { Certification }\end{array}$ & $\begin{array}{c}\text { University Qualified } \\
\text { Matriculation }\end{array}$ & $\begin{array}{c}\text { Summary } \\
\text { Index }\end{array}$ \\
& $(1)$ & $(3)$ & $(4)$ & $(5)$ \\
\hline i. Simple diff-in-diff $(\mathrm{N}=7706)$ & 0.016 & 2.387 & 0.078 & 0.083 & 0.135 \\
Grade-level treatment & $(0.009)$ & $(2.001)$ & $(0.033)$ & $(0.031)$ & $(0.064)$ \\
& 0.018 & 2.840 & 0.089 & 0.096 & 0.156 \\
Class-level treatment IV & $(0.013)$ & $(2.503)$ & $(0.073)$ & $(0.065)$ & $(0.111)$ \\
& & & & 0.094 & 0.153 \\
ii. Controlled diff-in-diff $(\mathrm{N}=7706)$ & 0.018 & 2.759 & 0.088 & $(0.029)$ & $(0.058)$ \\
Grade-level treatment & $(0.008)$ & $(1.838)$ & $(0.030)$ & 0.110 & 0.181 \\
& 0.021 & 3.338 & 0.102 & $(0.057)$ & $(0.094)$ \\
Class-level treatment IV & $(0.011)$ & $(2.194)$ & $(0.065)$ & & 0.575 \\
\end{tabular}

Note: This table reports an exercise in which we instrument a class-level treatment indicator with the grade-level indicator. More precisely, we define a treatment indicator that takes a value of 1 if there is a positive number of early reformers in the class, and a treatment indicator that takes a value of 1 if there is a positive number of early reformers in the grade, as well as their respective interactions with an indicator corresponding to the treated cohorts. The table presents the estimated coefficients of interest in a difference-in-differences regressions comparing students in treated and untreated classes who are treated (10th grade in 1999/2000) and untreated (10th grade in 1995/1996). The outcome variables are the same as in Table 4. 
Table A7: Descriptive Statistics: Treatment indicator ( 1 if Early Reformed $>0$ and Late Reformed $=0$ )

\begin{tabular}{lcccccc}
\hline \hline & \multicolumn{3}{c}{ Full } & \multicolumn{2}{c}{ Treated } & \multicolumn{2}{c}{ Control } \\
& Before & After & Before & After & Before & After \\
\hline Number of Schools & 18 & 16 &. &. &. &. \\
$\begin{array}{l}\text { Number of Grades (school/years) } \\
\text { Number of Students }\end{array}$ & 27 & 27 & 14 & 17 & 13 & 10 \\
$\quad \begin{array}{l}\text { I. Peers } \\
\text { II. Kibbutzniks }\end{array}$ & 1675 & 2285 & 550 & 1135 & 1125 & 1150 \\
$\quad$ i. Early reformers & 175 & 232 & 175 & 232 & 0 & 0 \\
$\quad$ ii. Late reformers & 112 & 87 & 0 & 0 & 112 & 87 \\
\hline
\end{tabular}

Note: A grade (school/year combination) is defined as treated if it includes students from early reformed kibbutzim. Kibbutzniks peers are those who share a grade with kibbutz members from early or late reformed kibbutzim. 
Table A8: Descriptive Statistics, Balancing and Post-Treatment Differences ( 1 if Early Reformed $>0$ and Late Reformed $=0$ )

\begin{tabular}{|c|c|c|c|c|c|c|c|c|}
\hline & \multicolumn{4}{|c|}{ 10th Grade Students in 1995 and 1996} & \multicolumn{4}{|c|}{ 10th Grade Students in 1999 and 2000} \\
\hline & $\begin{array}{l}\text { Full } \\
\text { (1) }\end{array}$ & $\begin{array}{l}\text { Treat- } \\
\text { ment } \\
(2)\end{array}$ & $\begin{array}{c}\text { Control } \\
\text { (3) }\end{array}$ & $\begin{array}{l}\text { Differ- } \\
\text { ence } \\
\text { (4) }\end{array}$ & $\begin{array}{l}\text { Full } \\
\text { (5) }\end{array}$ & $\begin{array}{l}\text { Treat- } \\
\text { ment } \\
(6)\end{array}$ & $\begin{array}{c}\text { Control } \\
\text { (7) }\end{array}$ & $\begin{array}{l}\text { Differ- } \\
\text { ence } \\
(8)\end{array}$ \\
\hline \multicolumn{9}{|l|}{ A. Student's characteristics } \\
\hline Male Indicator & $\begin{array}{c}0.512 \\
(0.500)\end{array}$ & $\begin{array}{c}0.476 \\
(0.500)\end{array}$ & $\begin{array}{c}0.536 \\
(0.499)\end{array}$ & $\begin{array}{c}-0.060 \\
(0.018)\end{array}$ & $\begin{array}{c}0.507 \\
(0.500)\end{array}$ & $\begin{array}{c}0.514 \\
(0.500)\end{array}$ & $\begin{array}{c}0.512 \\
(0.500)\end{array}$ & $\begin{array}{c}-0.004 \\
(0.025)\end{array}$ \\
\hline Father Years of Schooling & $\begin{array}{c}13.449 \\
(3.459)\end{array}$ & $\begin{array}{c}14.403 \\
(2.965)\end{array}$ & $\begin{array}{c}13.022 \\
(3.773)\end{array}$ & $\begin{array}{c}1.372 \\
(0.610)\end{array}$ & $\begin{array}{c}13.653 \\
(3.459)\end{array}$ & $\begin{array}{c}14.372 \\
(3.038)\end{array}$ & $\begin{array}{c}13.358 \\
(3.554)\end{array}$ & $\begin{array}{l}1.000 \\
(0.623)\end{array}$ \\
\hline Mother Year & $\begin{array}{c}13.523 \\
(3.114)\end{array}$ & $\begin{array}{c}14.381 \\
(2.695)\end{array}$ & $\begin{array}{c}13.136 \\
(3.336)\end{array}$ & $\begin{array}{c}1.240 \\
(0.411)\end{array}$ & $\begin{array}{c}13.926 \\
(3.114)\end{array}$ & $\begin{array}{c}14.461 \\
(2.811)\end{array}$ & $\begin{array}{c}13.535 \\
(3.231)\end{array}$ & $\begin{array}{c}0.933 \\
(0.488)\end{array}$ \\
\hline Numb & $\begin{array}{c}2.449 \\
(1.361)\end{array}$ & $\begin{array}{c}2.224 \\
(1.122)\end{array}$ & $\begin{array}{c}2.587 \\
(1.587)\end{array}$ & $\begin{array}{c}-0.360 \\
(0.380)\end{array}$ & $\begin{array}{c}2.300 \\
(1.361)\end{array}$ & $\begin{array}{c}2.342 \\
(1.102)\end{array}$ & $\begin{array}{c}2.238 \\
(1.134)\end{array}$ & $\begin{array}{c}0.112 \\
(0.226)\end{array}$ \\
\hline Asia-Africa Ethnicity & $\begin{array}{c}0.212 \\
(0.409)\end{array}$ & $\begin{array}{c}0.138 \\
(0.345)\end{array}$ & $\begin{array}{c}0.244 \\
(0.429)\end{array}$ & $\begin{array}{c}-0.104 \\
(0.058)\end{array}$ & $\begin{array}{c}0.184 \\
(0.409)\end{array}$ & $\begin{array}{c}0.145 \\
(0.353)\end{array}$ & $\begin{array}{c}0.209 \\
(0.407)\end{array}$ & $\begin{array}{l}-0.067 \\
(0.062)\end{array}$ \\
\hline Europe-America Ethnicity & $\begin{array}{c}0.213 \\
(0.410)\end{array}$ & $\begin{array}{c}0.264 \\
(0.441)\end{array}$ & $\begin{array}{c}0.192 \\
(0.394)\end{array}$ & $\begin{array}{c}0.072 \\
(0.030)\end{array}$ & $\begin{array}{c}0.192 \\
(0.410)\end{array}$ & $\begin{array}{c}0.229 \\
(0.420)\end{array}$ & $\begin{array}{l}0.1 \\
(0.1\end{array}$ & $\begin{array}{c}0.062 \\
(0.030)\end{array}$ \\
\hline Other Ethnicity & $\begin{array}{c}0.005 \\
(0.073)\end{array}$ & $\begin{array}{c}0.004 \\
(0.060)\end{array}$ & $\begin{array}{c}0.008 \\
(0.089)\end{array}$ & $\begin{array}{c}-0.004 \\
(0.003)\end{array}$ & $\begin{array}{c}0.009 \\
(0.073)\end{array}$ & $\begin{array}{c}0.017 \\
(0.128)\end{array}$ & $\begin{array}{c}0.006 \\
(0.078)\end{array}$ & $\begin{array}{c}0.011 \\
(0.006)\end{array}$ \\
\hline Former Soviet Union Ethnicity & $\begin{array}{c}0.053 \\
(0.224)\end{array}$ & $\begin{array}{c}0.071 \\
(0.257)\end{array}$ & $\begin{array}{c}0.064 \\
(0.245)\end{array}$ & $\begin{array}{c}0.008 \\
(0.050)\end{array}$ & $\begin{array}{c}0.056 \\
(0.224)\end{array}$ & $\begin{array}{c}0.043 \\
(0.203)\end{array}$ & $\begin{array}{c}0.055 \\
(0.228)\end{array}$ & $\begin{array}{l}-0.010 \\
(0.019)\end{array}$ \\
\hline Ethiop & $\begin{array}{c}0.007 \\
(0.083)\end{array}$ & $\begin{array}{c}0.000 \\
(0.000)\end{array}$ & $\begin{array}{c}0.015 \\
(0.122)\end{array}$ & $\begin{array}{c}-0.016 \\
(0.008)\end{array}$ & $\begin{array}{c}0.017 \\
(0.083)\end{array}$ & $\begin{array}{c}0.009 \\
(0.093)\end{array}$ & $\begin{array}{c}0.032 \\
(0.177)\end{array}$ & $\begin{array}{c}-0.023 \\
(0.016)\end{array}$ \\
\hline \multicolumn{9}{|l|}{ B. High School Outcomes } \\
\hline : & $\begin{array}{c}0.955 \\
(0.207)\end{array}$ & $\begin{array}{c}0.949 \\
(0.220)\end{array}$ & $\begin{array}{c}0.960 \\
(0.196)\end{array}$ & $\begin{array}{c}-0.011 \\
(0.015)\end{array}$ & $\begin{array}{c}0.961 \\
(0.207)\end{array}$ & $\begin{array}{c}0.952 \\
(0.215)\end{array}$ & $\begin{array}{c}0.958 \\
(0.200)\end{array}$ & $\begin{array}{c}-0.007 \\
(0.013)\end{array}$ \\
\hline Mean Matriculation Score & $\begin{array}{c}70.892 \\
\quad( \\
21.609)\end{array}$ & $\begin{array}{c}72.711 \\
( \\
20.941)\end{array}$ & $\begin{array}{c}70.421 \\
21.423)\end{array}$ & $\begin{array}{c}2.229 \\
(2.319)\end{array}$ & $\begin{array}{c}74.010 \\
( \\
21.609)\end{array}$ & $\begin{array}{c}74.266 \\
( \\
20.684)\end{array}$ & $\begin{array}{c}72.084 \\
( \\
19.977)\end{array}$ & $\begin{array}{c}2.187 \\
(1.692)\end{array}$ \\
\hline Matriculation Certification & $\begin{array}{c}0.616 \\
(0.487)\end{array}$ & $\begin{array}{c}0.662 \\
(0.474)\end{array}$ & $\begin{array}{c}0.614 \\
(0.487)\end{array}$ & $\begin{array}{c}0.047 \\
(0.059)\end{array}$ & $\begin{array}{c}0.687 \\
(0.487)\end{array}$ & $\begin{array}{c}0.699 \\
(0.459)\end{array}$ & $\begin{array}{c}0.630 \\
(0.483)\end{array}$ & $\begin{array}{c}0.069 \\
(0.045)\end{array}$ \\
\hline University Qualified Matriculation & $\begin{array}{c}0.575 \\
(0.494)\end{array}$ & $\begin{array}{c}0.633 \\
(0.483)\end{array}$ & $\begin{array}{c}0.570 \\
(0.495)\end{array}$ & $\begin{array}{c}0.062 \\
(0.063)\end{array}$ & $\begin{array}{c}0.632 \\
(0.494)\end{array}$ & $\begin{array}{c}0.659 \\
(0.474)\end{array}$ & $\begin{array}{c}0.568 \\
(0.496)\end{array}$ & $\begin{array}{c}0.093 \\
(0.060)\end{array}$ \\
\hline Observations & 3177 & 550 & 1125 & & 4529 & 1135 & 1150 & \\
\hline
\end{tabular}

Note: Columns 1 and 5 present means and standard deviations (in parentheses) of background characteristics and outcomes of students before and after the early reforms. Columns 2, 3, 6 and 7 present the means and standard deviations for students in treatment and control grades for affected (1999-2000) and unaffected (1995-1996) cohorts of 10th graders. Columns 4 and 8 present the differences between treatment and control grades, controlling for cohort fixed effects. The treatment group is defined as being comprised by grades in which the number of students from early reformed kibbutzim is greater than zero and the number of students from late reformed kibbutzim is equal to zero. 
Table A9: Short-Term Effects on High-School Outcomes ( 1 if Early Reformed $>0$ and Late Reformed $=0$ )

\begin{tabular}{cccccc}
\hline \hline & $\begin{array}{c}\text { High School } \\
\text { Completion }\end{array}$ & $\begin{array}{c}\text { Mean } \\
\text { Matriculation } \\
\text { Score } \\
(1)\end{array}$ & $\begin{array}{c}\text { Matriculation } \\
\text { Certification }\end{array}$ & $\begin{array}{c}\text { University Qualified } \\
\text { Matriculation }\end{array}$ & $\begin{array}{c}\text { Summary } \\
\text { Index }\end{array}$ \\
\hline i. Full Sample (N=3957) & & $(3)$ & $(4)$ & $(5)$ \\
Simple diff-in-diff & 0.010 & 0.582 & 0.031 & 0.044 & 0.058 \\
Controlled diff-in-diff & $(0.012)$ & $(2.081)$ & $(0.033)$ & $(0.032)$ & $(0.067)$ \\
& 0.009 & 1.114 & 0.051 & 0.065 & 0.084 \\
& $(0.011)$ & $(1.759)$ & $(0.031)$ & $(0.032)$ & $(0.059)$ \\
\hline
\end{tabular}

Note: This table replicates the results in Table 4 using the alternative definition of treatment as described in the previous table.

Table A10: Long-Term Effects on Post-Secondary Schooling Outcomes, Controlling for Family Income

\begin{tabular}{|c|c|c|c|c|c|c|}
\hline & \multicolumn{2}{|c|}{ All post secondary } & \multicolumn{2}{|c|}{ University } & \multicolumn{2}{|c|}{ College } \\
\hline & $\begin{array}{l}\text { Enroll- } \\
\text { ment } \\
(1)\end{array}$ & $\begin{array}{c}\text { Years od } \\
\text { schooling } \\
\text { (2) }\end{array}$ & $\begin{array}{c}\text { Enroll- } \\
\text { ment } \\
(3)\end{array}$ & $\begin{array}{c}\text { Years of } \\
\text { schooling } \\
\text { (4) }\end{array}$ & $\begin{array}{l}\text { Enroll- } \\
\text { ment } \\
(5)\end{array}$ & $\begin{array}{c}\text { Years of } \\
\text { schooling } \\
\text { (6) }\end{array}$ \\
\hline \multicolumn{7}{|l|}{ i. Full sample $(\mathrm{N}=7178)$} \\
\hline Simple diff-in-diff & $\begin{array}{c}0.040 \\
(0.021)\end{array}$ & $\begin{array}{c}0.235 \\
(0.191)\end{array}$ & $\begin{array}{c}0.087 \\
(0.034)\end{array}$ & $\begin{array}{c}0.487 \\
(0.183)\end{array}$ & $\begin{array}{l}-0.043 \\
(0.036)\end{array}$ & $\begin{array}{l}-0.165 \\
(0.113)\end{array}$ \\
\hline Controlled diff-in-diff & $\begin{array}{c}0.046 \\
(0.021)\end{array}$ & $\begin{array}{c}0.263 \\
(0.206)\end{array}$ & $\begin{array}{c}0.093 \\
(0.040)\end{array}$ & $\begin{array}{c}0.494 \\
(0.208)\end{array}$ & $\begin{array}{l}-0.038 \\
(0.037)\end{array}$ & $\begin{array}{l}-0.149 \\
(0.122)\end{array}$ \\
\hline \multicolumn{7}{|l|}{ ii. Stratification by gender } \\
\hline Male $(\mathrm{N}=3015)$ & $\begin{array}{c}0.068 \\
(0.033)\end{array}$ & $\begin{array}{c}0.572 \\
(0.246)\end{array}$ & $\begin{array}{c}0.133 \\
(0.040)\end{array}$ & $\begin{array}{c}0.795 \\
(0.203)\end{array}$ & $\begin{array}{l}-0.089 \\
(0.059)\end{array}$ & $\begin{array}{l}-0.223 \\
(0.169)\end{array}$ \\
\hline Female $(\mathrm{N}=2911)$ & $\begin{array}{c}0.005 \\
(0.039)\end{array}$ & $\begin{array}{c}0.152 \\
(0.333)\end{array}$ & $\begin{array}{c}0.084 \\
(0.064)\end{array}$ & $\begin{array}{c}0.564 \\
(0.266)\end{array}$ & $\begin{array}{l}-0.069 \\
(0.037)\end{array}$ & $\begin{array}{l}-0.361 \\
(0.145)\end{array}$ \\
\hline \multicolumn{7}{|c|}{ iii. Stratification by mother's education } \\
\hline Low $(\mathrm{N}=3054)$ & $\begin{array}{l}-0.013 \\
(0.034)\end{array}$ & $\begin{array}{c}0.156 \\
(0.289)\end{array}$ & $\begin{array}{c}0.106 \\
(0.040)\end{array}$ & $\begin{array}{c}0.689 \\
(0.238)\end{array}$ & $\begin{array}{c}-0.158 \\
(0.053)\end{array}$ & $\begin{array}{c}-0.520 \\
(0.166)\end{array}$ \\
\hline High $(\mathrm{N}=2872)$ & $\begin{array}{c}0.084 \\
(0.024)\end{array}$ & $\begin{array}{c}0.568 \\
(0.205)\end{array}$ & $\begin{array}{c}0.113 \\
(0.045)\end{array}$ & $\begin{array}{c}0.695 \\
(0.193)\end{array}$ & $\begin{array}{c}0.011 \\
(0.036)\end{array}$ & $\begin{array}{c}-0.013 \\
(0.121)\end{array}$ \\
\hline
\end{tabular}

Note: This table replicates the results in Table 6 adding family income as an additional control variable. 
Table A11: Long-Term effects on Labor Market Outcomes, Controlling for Family Income

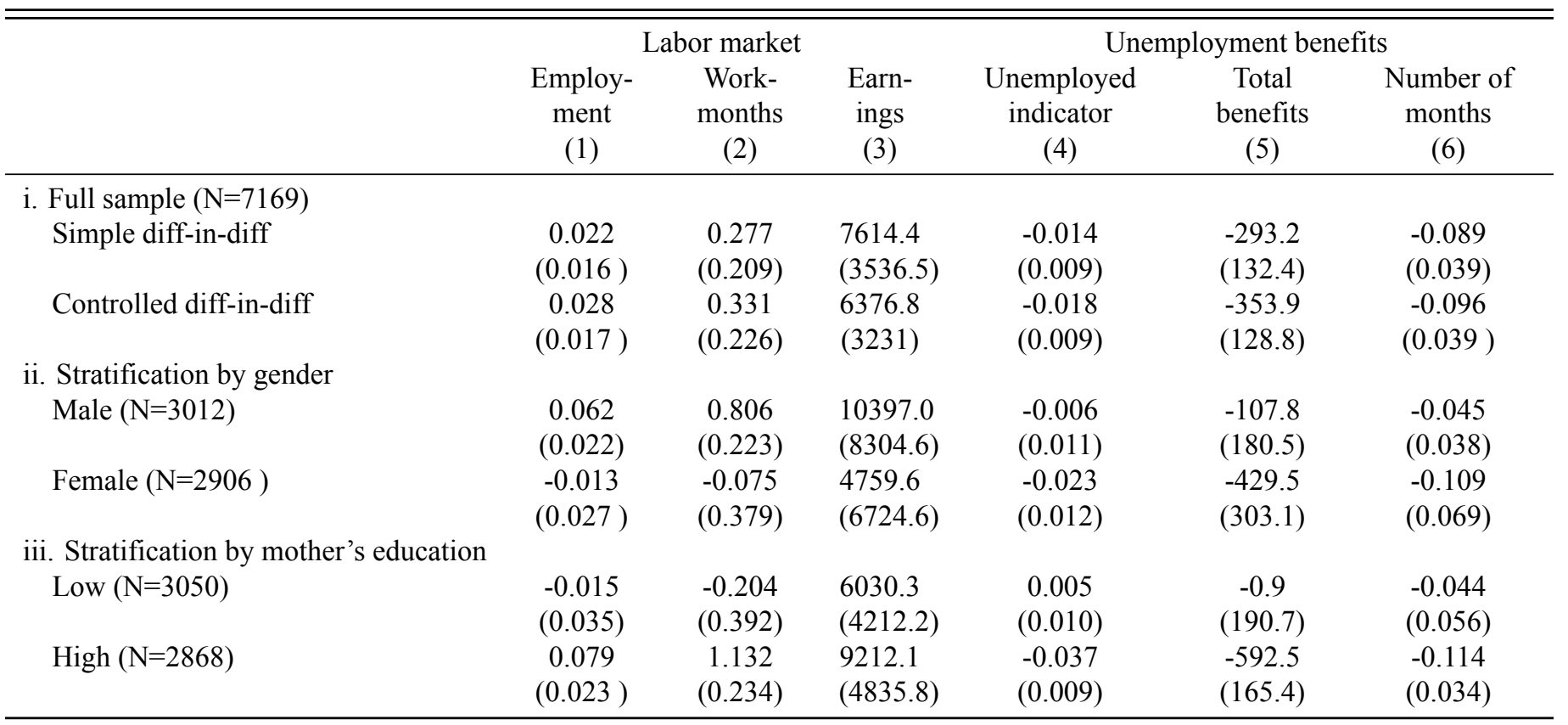

Note: This table replicates the results in Table 7 adding family income as an additional control variable.

Table A12: Long-Term Effects on Summary Index

\begin{tabular}{lcc}
\hline \hline & Post-secondary and labor market outcomes & University and labor market outcomes \\
& $(1)$ & $(2)$ \\
\hline i. Full sample $(\mathrm{N}=7555)$ & & \\
Simple diff-in-diff & $(0.031)$ & 0.104 \\
& 0.091 & $(0.031)$ \\
Controlled diff-in-diff & $(0.033)$ & 0.108 \\
& & $(0.032)$ \\
ii. Stratification by gender & 0.112 & 0.130 \\
Male (N=3151) & $(0.026)$ & $(0.031)$ \\
& 0.065 & 0.096 \\
Female (N=3072) & $(0.071)$ & $(0.066)$ \\
& & \\
iii. Stratification by mother's education & 0.030 & 0.068 \\
Low (N=3219) & $(0.040)$ & $(0.038)$ \\
& 0.159 & 0.170 \\
High ( $\mathrm{N}=3004)$ & $(0.040)$ & $(0.037)$ \\
\end{tabular}

Note: The full sample includes students that have at least 2 peers in a grade from reformed kibbutzim and the stratified samples include students that have at least 6 peers in grade from reformed kibbutzim. Standard errors clustered at the school level and presented in parentheses. 
Table A13: Effects on Percentile Ranking of Annual Earnings

\begin{tabular}{lc}
\hline \hline & $\begin{array}{c}\text { Percentile Ranking in } \\
(1)\end{array}$ \\
\hline i. Full sample (N=7524 ) & 4.27 \\
Simple difference-in-differences & $(1.62)$ \\
& 4.08 \\
Controlled difference-in-differences & $(1.75)$ \\
& 8.14 \\
ii. Sample stratification by gender (6+) & $(1.94)$ \\
Male (N=3137) & 1.52 \\
& $(2.90)$ \\
Female (N=3067) & 8.19 \\
& $(1.98)$ \\
iii. Sample stratification by mother's education $(6+)$ & 1.30 \\
Low (N=3521) & $(1.89)$ \\
High (N=2481) & \\
\end{tabular}

Note: In this table, we replace the income variable with the percentile ranking of an individual in the national income distribution.

Table A14: Effects on Summary Index, by Parental Occupation

\begin{tabular}{lcc}
\hline \hline & $\begin{array}{c}\text { Summary index } \\
\text { High-school outcomes } \\
(1)\end{array}$ & $\begin{array}{c}\text { Summary index all } \\
\text { post-secondary and labor market } \\
(2)\end{array}$ \\
\hline $\begin{array}{c}\text { i.All Sample }(\mathrm{N}=7555) \\
\text { Treatment X after }\end{array}$ & 0.146 & 0.091 \\
& $(0.056)$ & $(0.033)$ \\
$\begin{array}{l}\text { Independents }(\mathrm{N}=2311) \\
\text { Treatment X after }\end{array}$ & 0.192 & 0.118 \\
Salaried Workers $(\mathrm{N}=5244)$ & $(0.072)$ & $(0.040)$ \\
Treatment X after & 0.119 & 0.085 \\
& $(0.064)$ & $(0.042)$ \\
\hline
\end{tabular}

Note: This table shows the results on the short and long-run indexes, stratifying the sample based on whether the parents of peers were employed as salaried or independent workers. 
Table A15: Short-Term Effects on Type of Subjects Taken in High School, Direct Effects

\begin{tabular}{|c|c|c|c|c|c|c|}
\hline & $\begin{array}{l}\text { \# of Credit } \\
\text { Units } \\
\text { Received in } \\
\text { Bagrut } \\
\text { (1) }\end{array}$ & $\begin{array}{c}\text { \# of } \\
\text { Credit } \\
\text { Units in } \\
\text { English } \\
\text { (2) }\end{array}$ & $\begin{array}{l}\text { \# of } \\
\text { Credit } \\
\text { Units in } \\
\text { Math } \\
\text { (3) }\end{array}$ & $\begin{array}{c}\text { \# of } \\
\text { Subjects } \\
\text { in High } \\
\text { School } \\
\text { (4) }\end{array}$ & $\begin{array}{c}\# \text { of } \\
\text { Non-Science } \\
\text { Subjects in } \\
\text { High School } \\
\text { (5) }\end{array}$ & $\begin{array}{c}\text { \# of Science } \\
\text { Subjects in } \\
\text { High School } \\
\text { (6) }\end{array}$ \\
\hline \multicolumn{7}{|l|}{ i. Full sample $(\mathrm{N}=3223)$} \\
\hline Simple diff-in-diff & $\begin{array}{c}0.069 \\
(0.676)\end{array}$ & $\begin{array}{c}0.014 \\
(0.083)\end{array}$ & $\begin{array}{c}-0.070 \\
(0.114)\end{array}$ & $\begin{array}{c}0.171 \\
(0.225)\end{array}$ & $\begin{array}{c}0.675 \\
(0.340)\end{array}$ & $\begin{array}{c}-0.504 \\
(0.296)\end{array}$ \\
\hline Controlled diff-in-diff & $\begin{array}{c}0.032 \\
(0.679)\end{array}$ & $\begin{array}{c}-0.001 \\
(0.081)\end{array}$ & $\begin{array}{c}-0.077 \\
(0.112)\end{array}$ & $\begin{array}{c}0.161 \\
(0.227)\end{array}$ & $\begin{array}{c}0.670 \\
(0.343)\end{array}$ & $\begin{array}{c}-0.509 \\
(0.298)\end{array}$ \\
\hline \multicolumn{7}{|l|}{ ii. Stratification by Gender } \\
\hline Male $(\mathrm{N}=1638)$ & $\begin{array}{c}-0.175 \\
(1.139)\end{array}$ & $\begin{array}{c}-0.075 \\
(0.127)\end{array}$ & $\begin{array}{c}-0.143 \\
(0.183)\end{array}$ & $\begin{array}{c}0.295 \\
(0.353)\end{array}$ & $\begin{array}{c}0.933 \\
(0.401)\end{array}$ & $\begin{array}{c}-0.637 \\
(0.473)\end{array}$ \\
\hline Female $(\mathrm{N}=1585)$ & $\begin{array}{c}0.409 \\
(0.789)\end{array}$ & $\begin{array}{c}0.030 \\
(0.091)\end{array}$ & $\begin{array}{c}-0.036 \\
(0.163)\end{array}$ & $\begin{array}{c}0.093 \\
(0.275)\end{array}$ & $\begin{array}{c}0.423 \\
(0.504)\end{array}$ & $\begin{array}{c}-0.331 \\
(0.443)\end{array}$ \\
\hline \multicolumn{7}{|l|}{ iii. Stratification by Mother's Education } \\
\hline Low $(\mathrm{N}=1500)$ & $\begin{array}{c}0.371 \\
(1.041)\end{array}$ & $\begin{array}{c}-0.066 \\
(0.123)\end{array}$ & $\begin{array}{c}-0.047 \\
(0.180)\end{array}$ & $\begin{array}{c}0.244 \\
(0.361)\end{array}$ & $\begin{array}{c}0.757 \\
(0.474)\end{array}$ & $\begin{array}{c}-0.513 \\
(0.389)\end{array}$ \\
\hline High $(\mathrm{N}=1723)$ & $\begin{array}{c}-0.398 \\
(0.811)\end{array}$ & $\begin{array}{c}0.032 \\
(0.096)\end{array}$ & $\begin{array}{c}-0.156 \\
(0.136)\end{array}$ & $\begin{array}{c}0.023 \\
(0.274)\end{array}$ & $\begin{array}{c}0.579 \\
(0.455)\end{array}$ & $\begin{array}{c}-0.556 \\
(0.409)\end{array}$ \\
\hline Mean dependent variable (full sample) & 22.300 & 4.205 & 2.958 & 7.711 & 5.052 & 2.660 \\
\hline
\end{tabular}

Note: The first panel of the table presents the estimated coefficients of interest in difference-in-differences regressions, comparing students in treated and untreated grades who are treated (10th grade in 1999/2000) and untreated (10th grade in 1995/1996). A grade (school/year combination) is defined as treated if it includes students from early reformed kibbutzim. The simple difference-indifferences regressions include only cohort dummies and school fixed effects. The second panel of the table shows the controlled difference-in-differences, which also includes the following students demographic controls: gender, father's and mother's education, number of siblings, a set of ethnic dummies (origin from Africa/Asia, Europe/America, immigrants from FSU, Ethiopia and other countries). Standard errors clustered at the kibbutz level level and presented in parentheses. 